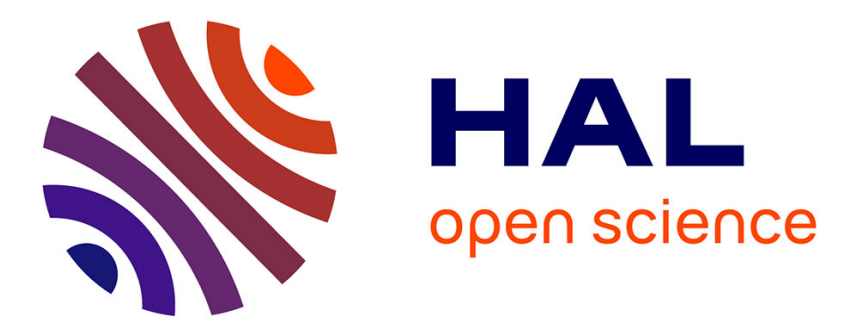

\title{
New tricks for an old dog a repurposing approach of apomorphine
}

Manon Auffret, Sophie Drapier, Marc Vérin

\section{To cite this version:}

Manon Auffret, Sophie Drapier, Marc Vérin. New tricks for an old dog a repurposing approach of apomorphine. European Journal of Pharmacology, 2019, 843, pp.66-79. 10.1016/j.ejphar.2018.10.052 . hal-01940273

\section{HAL Id: hal-01940273 \\ https://hal-univ-rennes1.archives-ouvertes.fr/hal-01940273}

Submitted on 3 Dec 2018

HAL is a multi-disciplinary open access archive for the deposit and dissemination of scientific research documents, whether they are published or not. The documents may come from teaching and research institutions in France or abroad, or from public or private research centers.
L'archive ouverte pluridisciplinaire HAL, est destinée au dépôt et à la diffusion de documents scientifiques de niveau recherche, publiés ou non, émanant des établissements d'enseignement et de recherche français ou étrangers, des laboratoires publics ou privés. 


\title{
ACCEPTED MANUSCRIPT
}

\section{New tricks for an old dog: a repurposing approach of apomorphine}

\author{
Manon Auffret ${ }^{1,2 *}$, Sophie Drapier ${ }^{1,2,3}$, Marc Vérin $^{1,2,3}$ \\ ${ }^{1}$ Behavior and Basal Ganglia Research Unit (EA 4712), University of Rennes 1, Rennes, France \\ ${ }^{2}$ Institut des Neurosciences Cliniques de Rennes (INCR), Rennes, France
}

${ }^{3}$ Movement Disorders Unit, Neurology Department, Pontchaillou University Hospital, Rennes, France

"Corresponding author: EA 4712 "Comportement et Noyaux Gris Centraux", Campus de Villejean - Bât. 40L27,

2 Rue Henri le Guilloux, 35033 Rennes Cedex, France, Tel.: + 336416009 05; auffret.manon@ gmail.com

ORCID ID: orcid.org/0000-0002-7003-4084

\begin{abstract}
Apomorphine is a 150-year old nonspecific dopaminergic agonist, currently indicated for treating motor fluctuations in Parkinson's disease. At the era of drug repurposing, its pleiotropic biological functions suggest other possible uses. To further explore new therapeutic and diagnostic applications, the available literature up to July 2018 was reviewed using the PubMed and Google Scholar databases. As many of the retrieved articles consisted of case reports and preclinical studies, we adopted a descriptive approach, tackling each area of research in turn, to give a broad overview of the potential of apomorphine. Apomorphine may play a role in neurological diseases like restless legs syndrome, Huntington's chorea, amyotrophic lateral sclerosis, Alzheimer's disease and disorders of consciousness, but also in sexual disorders, neuroleptic malignant(-like) syndrome and cancer. Further work is needed in both basic and clinical research; current developments in novel delivery strategies and apomorphine derivatives are expected to open the way.
\end{abstract}

Keywords: apomorphine, repurposing, neurodegenerative diseases, sexual disorders, neuroleptic malignant syndrome, cancer

\section{Introduction}

"[La thérapeutique médicale] a même, à notre avis, dans ses louables efforts, dépassé le but, en encombrant la science d'une multitude de médicaments nouveaux, qui ont eu l'inconvénient de faire oublier que, parmi les 


\section{ACCEPTED MANUSCRIPT}

anciens, et parmi les vieilles médications surtout, il y en a qui ont, depuis longtemps, fait leurs preuves et qui ne demandent qu'à être mieux étudiés, soit au laboratoire, soit à la clinique ». ${ }^{1}$ Dr Louis Guinard, 1898

Drug repurposing can be defined as the process of identifying new therapeutic opportunities for existing drugs (Mehndiratta et al, 2016; Corsello et al, 2017). Either drug-centered, disease-centered or target-centered, the repurposing approach is an efficient, accelerated and cost-effective way of fulfilling unmet medical needs and a promising alternative to the costly de novo drug discovery and development (Morales, 2001; Mehndiratta et al, 2016). If past repurposing successes have been largely the result of serendipity, large-scale efforts and systematic screening of approved and/or abandoned drugs are now conducted, with the help of bioinformatics (Corsello et al, 2017). According to Nobel-prized Sir James Whyte Black², old drugs are a "fruitful basis for the discovery of a new drug" (Raju, 2000). Now off patent, apomorphine was first synthesized in 1845, making it the oldest antiparkinsonian drug. Its clinical use dates back to 1869 and the work of Dr Samuel Jones Gee, who introduced it into the therapeutic armamentarium as a powerful emetic (Auffret et al, 2018a). Following this experimental discovery, apomorphine was empirically used for a multitude of indications, ranging from antipoisoning to expectoration (Auffret et al, 2018a). The discovery of its dopaminergic mechanism of action, along with the synthesis of domperidone (a peripheral dopaminergic antagonist), prompted its rational use as an antiparkinsonian drug at the end of the 1980's (Auffret et al, 2018a). This target-centered approach of a drug previously known as an emetic can therefore be considered as the first major repositioning of apomorphine.

However, the rich empirical history, complex pharmacological profile and pleiotropic biological functions of this 150-year old drug (Ribarič, 2012; Auffret et al, 2018b) suggest further therapeutic and diagnostic applications. To investigate its full potential, we conducted a review of the available French and English literature up to July 2018, using the PubMed and Google Scholar databases. Reference lists from relevant studies were screened for additional references. As many of the retrieved articles consisted of case reports and preclinical studies, we adopted a descriptive approach, tackling each area of research in turn and compiling clinical data with recent neuromolecular probes. The search identified several potential repurposing opportunities for apomorphine: restless legs syndrome, Huntington's disease, disorders of consciousness, amyotrophic lateral sclerosis, Alzheimer's disease, erectile dysfunction, female sexual disorder, neuroleptic malignant(-like) syndrome and

\footnotetext{
1 "In our opinion, the medical therapeutics has, with much admirable effort, exceeded her goal, by saddling science with a multitude of new drugs, which have had the disadvantage of making us forget that, among the ancients, and especially among the old medications, there are some which have, for a long time, proved their worth and are longing to be better studied, either in the laboratory or in the clinic."

${ }^{2}$ The Nobel Prize in Physiology or Medicine for 1988 was awarded jointly to Sir James W. Black (1924-2010), Gertrude B. Elion (1918-1999) and George H. Hitchings (1905-1998) for their discoveries of "important principles for drug treatment".
} 


\section{ACCEPTED MANUSCRIPT}

cancer. Both descriptive and critical, this work aims at giving a broad overview of the potential of apomorphine, to guide basic and clinical research. Proposed mode and sites of action, as well as references of these possible new indications are displayed in Table 1.

Table 1: Repurposing opportunities for apomorphine: summary of the possible indications and associated mechanisms. AD: Alzheimer's disease; ERK: extracellular signal-regulated kinases; IRS-1: insulin receptor substrate 1; NDEA: N-nitrosodiethylamine; Nrf2-ARE: NF-E2-related factor 2 antioxidant responsive element; PKC/A: phosphokinase C/A; PLMS: periodic limb movements during sleep; ROS: reactive oxygen species

\begin{tabular}{|c|c|c|c|}
\hline $\begin{array}{l}\text { Possible } \\
\text { indication }\end{array}$ & Proposed mode and/or site of action & Major & $\begin{array}{l}\text { Clinical studies } \\
\text { and number of } \\
\text { patients included }\end{array}$ \\
\hline $\begin{array}{l}\text { Restless leg } \\
\text { syndrome (RLS) } \\
\text { and/or periodic } \\
\text { limb movements } \\
\text { during sleep } \\
\text { (PLMS) }\end{array}$ & $\begin{array}{l}\text { - Unclear } \\
\text { - Correction of the dopaminergic } \\
\text { imbalance? }\end{array}$ & None & $\begin{array}{l}\text { Reuter et al, } 1999 \\
(\mathrm{~N}=8) \\
\text { Paradiso et al, } \\
2002(\mathrm{~N}=1) \\
\text { Haba-Rubio et al, } \\
2003 \text { (N=9) } \\
\text { Tribl et al, } 2005 \\
(\mathrm{~N}=9) \\
\text { Tings et al, } 2005 \\
(\mathrm{~N}=1) \\
\text { Müller et al, } 2014 \\
(\mathrm{~N}=1)\end{array}$ \\
\hline Huntington's & - Unclear & Sanberg et al, 1979 & Tolosa \& Sparber, \\
\hline disease (HD) & $\begin{array}{l}\text { - Dopamine receptor stimulation? } \\
\text { - Stimulation of other } \\
\text { neurotransmitters/neuropeptides pathways? }\end{array}$ & (Wistar rats) & $\begin{array}{l}1974(\mathrm{~N}=4) \\
\text { Corsini et al, } 1978 \\
(\mathrm{~N}=4)\end{array}$ \\
\hline
\end{tabular}


- Sedative action? (unlikely)

Caraceni et al,

$1980(\mathrm{~N}=4)$

Albanese et al,

$1995(\mathrm{~N}=9)$

Vitale et al, 2007

$(\mathrm{N}=9)$

\begin{tabular}{|c|c|c|c|}
\hline Disorders of & - Unclear & None & Fridman et al, \\
\hline consciousness & $\begin{array}{l}\text { - Correction of a dopaminergic deficit in } \\
\text { the nigrostriatal, mesolimbic, mesocortical } \\
\text { and/or thalamic pathways } \\
\text { - Trophic activity? } \\
\text { - Neurorecovery properties? }\end{array}$ & . & $\begin{array}{l}2009(\mathrm{~N}=1) \\
\text { Fridman et al, } \\
2010\left(\mathrm{~N}=8^{*}\right) \\
\text { *including the } \\
\text { same patient than } \\
\text { Fridman et al, } \\
2009\end{array}$ \\
\hline $\begin{array}{l}\text { Amyotrophic } \\
\text { lateral sclerosis } \\
\text { (ALS) }\end{array}$ & $\begin{array}{l}\text { - Neuroprotection: decrease of oxidative } \\
\text { stress } \\
\text { - Nrf2-ARE activation } \\
\text { - Glutaminase inhibition? }\end{array}$ & $\begin{array}{l}\text { Mead et al, } 2013 \\
\text { (mouse and patient } \\
\text { fibroblast) }\end{array}$ & $\begin{array}{l}\text { None at the time of } \\
\text { our writing }\end{array}$ \\
\hline $\begin{array}{l}\text { Alzheimer's } \\
\text { disease (AD) }\end{array}$ & $\begin{array}{l}\text { - Anti-amyloidogenic effect } \\
\text { (intraneuronal) } \\
\text { - Reduction of brain insulin resistance } \\
\text { - Neuroprotection: decrease of oxidative } \\
\text { stress } \\
\text { - Reduction of p53 levels }\end{array}$ & $\begin{array}{l}\text { Lashuel et al, } 2002 \\
\text { (electron microscopy); } \\
\text { Himeno et al, } 2011 \\
\text { (3xTg-AD mice); Ma et } \\
\text { al, } 2011 \text { (mice, SH- } \\
\text { SY5Y neuroblastoma } \\
\text { cells); Nakamura et al, } \\
2017 \text { (3xTg-AD mice); } \\
\text { Hanaki et al, } 2018 \\
\text { (SH-SY5Y } \\
\text { neuroblastoma cells) }\end{array}$ & $\begin{array}{l}\text { Yarnall et al, } 2016 \\
\text { (N=36, amyloid- } \\
\text { burden in } \\
\text { parkinsonian } \\
\text { brains with } \\
\text { antemortem } \\
\text { exposure to } \\
\text { apomorphine } \\
\text { therapy) } \\
\text { Nakamura et al, } \\
\text { 2017 (mention of } \\
\text { unpublished data }\end{array}$ \\
\hline
\end{tabular}


Erectile

dysfunction

Female sexual

dysfunction

Neuroleptic

Malignant

Syndrome

Neuroleptic- Like

Malignant

Syndrome
- Central and spinal stimulation of

dopaminergic pathways (dopamine $\mathrm{D}_{2}$-like

receptors in the paraventricular nucleus of

the hypothalamus)

- Peripheral action on the corpus

cavernosum (dopamine $\mathrm{D}_{1}$-like receptors

and nitric oxide release from endothelium)

- Stimulation of the medial preoptic

hypothalamus area and/or paraventricular

nuclei

- Nonadrenergic-noncholinergic pathway and modulation of nitric oxide

- Unclear

- Correction of the dopaminergic

imbalance?
Butcher et al, 1969 Heaton,

(rats); Tagliamonte et $\quad 2001(\mathrm{~N}=270)$

al, 1974 (Wistar rats) Heaton et al, 2002

Matsumoto et al, $2005 \quad(\mathrm{~N}=310)$

(rats); d'Emmanuele Caruso et al, 2003

di Villa Bianca et al, $\quad(\mathrm{N}=34)$

2005 (human corpus Perimenis et al,

cavernosum cells) $2004(\mathrm{~N}=40)$

Hamburger-Bar \& Bechara et al, 2004

Rigter, 1975 (Wistar

$(\mathrm{N}=24)$

derived rats); Tarcan

Caruso et al, 2004

et al, 2000 (rabbits);

$(\mathrm{N}=50)$

Beharry et al, 2003

(Wistar rats); Graham

\& Pfaus, 2008 (Long-

Evans rats)

None

Wang \& Hsieh,

$2001(\mathrm{~N}=1)$

Lattanzi et al, 2006

$(\mathrm{N}=1)$

Cunningham et al,

$1991(\mathrm{~N}=1)$

Bonuccelli et al,

$1992(\mathrm{~N}=1)$

Douglas \& Morris,

$2006(\mathrm{~N}=1)$

Gambassi et al,

$2006(\mathrm{~N}=1)$

Cancer

- Glutaminase inhibition (neoplasia and
In vitro: Kondo et al, 


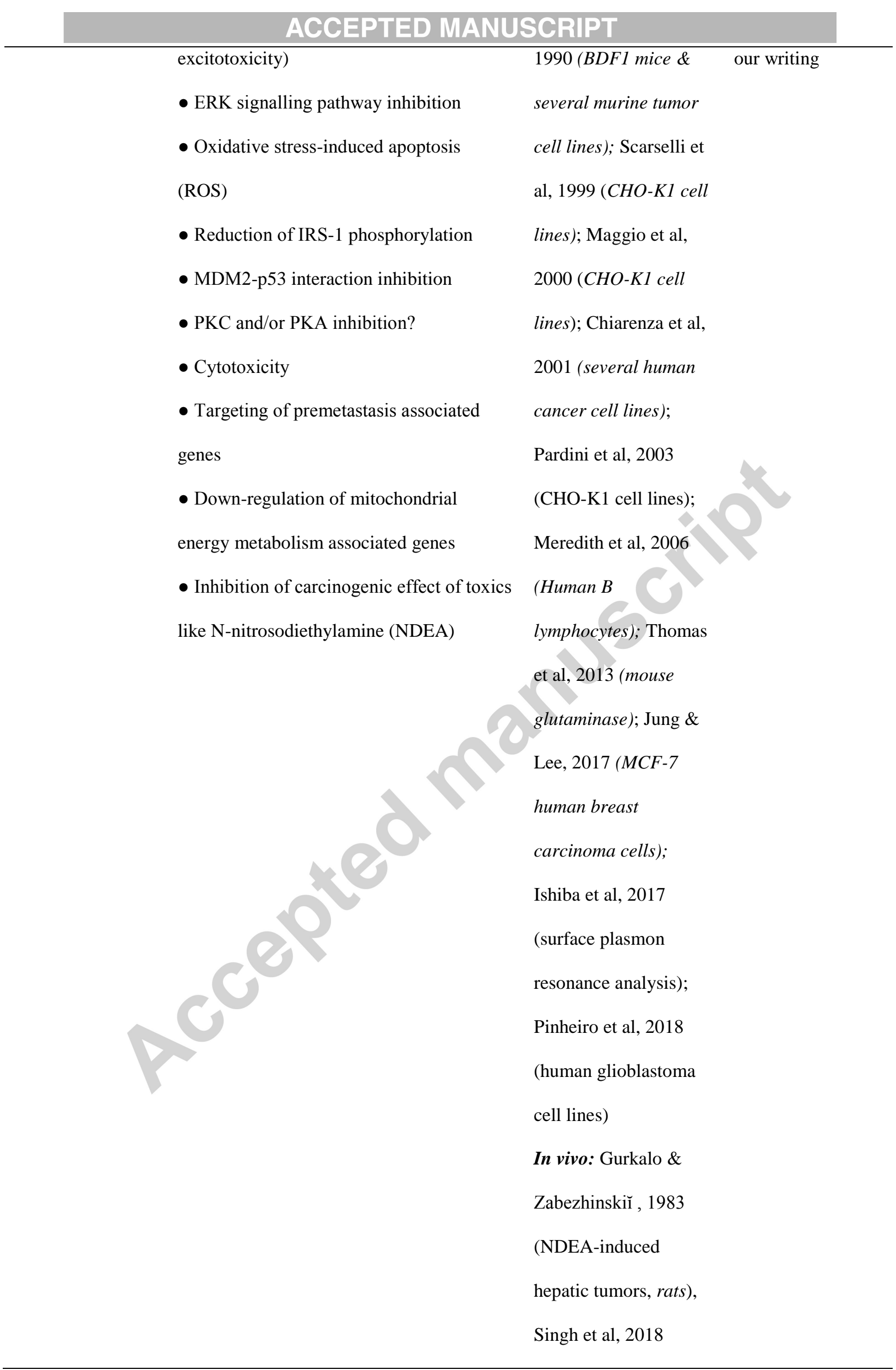




\section{Pharmacological targets of apomorphine}

Apomorphine $\left(\mathrm{C}_{17} \mathrm{H}_{17} \mathrm{NO}_{2}\right)$ is an aporphine alkaloid derived from morphine, with a number of pharmacological targets, excluding opioid receptors (Ribarič, 2012; Schulze et al, 2013; Auffret et al, 2018b). The mechanistic underpinning its pleiotropic biological functions is both dopaminergic and non-dopaminergic (Ribarič, 2012; Auffret et al, 2018b). The semirigid and polycyclic structure (Fig.1) accounts for the dopaminergic activity (catechol moiety) and the rapid crossing of the blood-brain-barrier (lipophilicity). The chiral center of the dopamine moiety (6-a, Fig. 1) results in two enantiomers, namely R-(-)-apomorphine (currently used in therapeutics) and S-(+)-apomorphine (Fig. 1, with the same chemical structure but different pharmacological profiles (Auffret et al, 2018b).

A<smiles>CN1CCc2cccc3c2[C@@H]1Cc1ccc(O)c(O)c1-3</smiles>

B<smiles>CN1CCc2cccc3c2[C@@H]1Cc1ccc(O)c(O)c1-3</smiles>

$\mathrm{S}-(+)$-apomorphine is a dopaminergic antagonist (dopamine $\mathrm{D}_{1}$-like and $\mathrm{D}_{2}$-like receptors) and a serotonergic antagonist (serotonergic 5-HT3 receptor) whereas R-(-)-apomorphine acts as an agonist on every subtypes of dopaminergic receptors (with variable affinities and a biphasic effect) and as a partial agonist at the serotonergic 5-HT 3 receptor (Goldman \& Kebabian, 1984; Ribarič, 2012; Auffret et al, 2018a). R-(-)-apomorphine has been used as a neuroendocrine probe of central dopaminergic activity in various disorders (e.g Parkinson's disease PD, psychiatric disorders, addictions), with measurement of prolactin and growth hormone (GH) levels before and after apomorphine administration (Friess et al, 2001; Guardia et al, 2002; Brunerova et al, 2012; Auffret et al, 2018b). Though poorly explored, R-(-)-apomorphine also acts on the serotonergic and adrenergic systems 


\section{ACCEPTED MANUSCRIPT}

(Ribarič, 2012; Auffret et al, 2018b). Human transient receptor potential A (TRPA1) is also modulated by R-(-)apomorphine, suggesting a role in sensory processes, with low doses inducing irreversible activation, and high doses causing a reduction of single-channel open times (Schulze et al, 2013). In vitro, ex vivo and in vivo studies have also shown that R-(-)- and S-(+)-apomorphine display both neuroprotection and neurotoxicity through several mechanisms (Guo et al, 2002; Kyriasis, 2003; Yuan et al, 2004; Picada et al, 2005; Auffret et al, 2018b). They involve trophic factor induction (BDNF Guo et al, 2002; FGF-2 Li et al, 2006; GDNF Ohta et al, 2000, Guo et al, 2002; NGF Ohta et al, 2000), radical scavenging (Ubeda et al, 1993; Hara et al, 2006), metal scavenging (Ubeda et al, 1993; Youdim et al, 1999), oxidant and antioxidant activity (Ubeda et al 1993; Gassen et al 1996, 1998; Grünblatt et al, 1999a, 1999b, 2001; dos Santos El Bacha et al 2001; Battaglia et al, 2002; Kyriasis, 2003; Pardini et al 2003 ; Mandel et al, 2004; ; Picada et al, 2005 ; Castri et al, 2006; Hara et al, 2006; Himeno et al, 2011; Ma et al, 2011), activation of anti-inflammatory pathways (Hara et al, 2006) and apoptosis modulation (Gassen et al, 1996; Pardini et al 2003, Ma et al, 2011). Depending on the dose, duration and cell types, apomorphine can therefore be cytoprotective, cytostatic or even cytotoxic. Finally, R-(-)- and S-(+)apomorphine inhibit the monoamine oxidase A and B, as well as the tyrosine hydroxylase (Grünblatt et al, 2001; Auffret et al, 2018b)

Apomorphine acts on dopaminergic pathways, which makes it an interesting candidate in the treatment of dopaminergic disorders, such as Parkinson's disease (PD), but also restless legs syndrome, neuroleptic(-like) malignant syndrome or sexual disorders. Its potential role in counteracting neuroinflammation and oxidative stress could be critical in the pathogenesis of many neurological disorders, including PD, Alzheimer's disease (AD), amyotrophic lateral sclerosis (ALS) or Huntington's disease (HD). Finally, its modulation of apoptosis makes it a good candidate for future cancer therapies.

\section{Apomorphine and neurological diseases}

Apomorphine was first associated with choreic movements at the end of the XIX ${ }^{\text {th }}$ century, with the work of Pierce (1870) and Edmond Weill (1884) (Auffret et al, 2018a). It is currently indicated for parkinsonian motor fluctuations resistant to oral treatment. Though still underused, its interest in PD extends beyond motor disorders, with new data emerging on its efficacy on nonmotor symptoms and its potential value when administered earlier in the course of the disease (Auffret et al, 2018a,b). Its rapid onset, short duration of action, way of administration (subcutaneous and acute $v s$ chronic) and pleiotropic biological functions point out towards 


\section{ACCEPTED MANUSCRIPT}

various other uses in neurological diseases, supported by preclinical data (AD, ALS) and clinical studies (RLS, HD, disorders of consciousness).

\subsection{Restless legs syndrome (RLS) and periodic limb movements during sleep (PLMS)}

RLS is a common sensorimotor disorder associated with brain iron deficiency, neurotransmission abnormalities in the dopaminergic $\left(\mathrm{D}_{2}\right.$-receptors) and opiate systems, and abnormal activity in a distributed cortical and subcortical network (Mano \& Thomas, 2018). The fact that the apomorphine challenge ( 0.005 $\mathrm{mg} / \mathrm{kg}$ of body weight) does not induce a GH increase in RLS patients (contrary to PD) support the hypothesis that RLS is not solely a dopaminergic disorder (Happe et al, 2007). Either primary (familial) or secondary (druginduced, uraemia, iron deficiency), RLS appears to be more prevalent in neurodegenerative diseases such as PD and multiple system atrophy (MSA) (Reuter et al, 1999; Tribl et al, 2005; Tings et al, 2005; Ghorayeb et al, 2014). Leg paresthesias and/or dysesthesias, occurring at rest, causing an urge to move, are characteristics, and usually relieved by movement (Happe et al, 2007; Mano \& Thomas, 2018). Symptoms often worsen at night and negatively affect sleep and quality of life (Happe et al, 2007). Abnormal periodic legs/limbs movements during wakefulness (PLMW) or sleep (PLMS), consisting of episodes of stereotyped limb movements, are commonly associated with RLS (Paradiso et al, 2002; Haba-Rubio et al, 2003; Tribl et al, 2005; Happe et al, 2007). In a recent evidence-based review examining current treatment for RLS, levodopa and a few dopaminergic agonists (ropinirole, rotigotine, cabergoline, pramipexole) were deemed "efficacious at an acceptable risk", with special monitoring (Winkelmann et al, 2018). Apomorphine was not mentioned in this review. However, five case reports (Reuter et al, 1999; Haba-Rubio et al, 2002; Paradiso et al, 2002; Tings et al, 2005; Müller et al, 2014) and one cases series (Tribl et al, 2005) support its potential interest in treating RLS and/or PLMS, either through acute injections or continuous infusion. Nocturnal apomorphine infusion was evaluated in two RLS patients (46 and 58 years, idiopathic RLS and RLS secondary to PD) with PLMS (not assessed during the study) and nocturnal symptoms refractory to conventional oral therapy, with one double-blind trial with placebo (Reuter et al, 1999). Overnight monotherapy (12 $\mathrm{mg}$ and $18 \mathrm{mg}$ ) led to a significant reduction in nocturnal discomfort and leg movements, as well as an improvement in pain and spasm scores (Reuter et al, 1999). Both patients continued nocturnal apomorphine infusion after discharge and reported a persistent benefit on sleep, as well as an improvement in daily living activities during the mean follow-up of 12 months (Reuter et al, 1999). In another study (Tings et al, 2005), a 38-year old female patient with short bowel syndrome and uncontrollable uraemic RLS was successfully treated by subcutaneous (SC) injections of apomorphine (1 mg) administered at nighttime 


\section{ACCEPTED MANUSCRIPT}

and before each hemodialysis. RLS symptoms were reduced (IRLSRS ${ }^{3}$ score) and concomitant treatment (fentanyl and pirtramid) tapered off. After six months, the patient remained stable, with one or two selfinjections per day. A prospective and open-label study evaluated the efficacy of apomorphine in nine consecutive patients (5 male, mean age 55.3 years) with severe idiopathic RLS (Tribl et al, 2005). Apomorphine was first administered as a bolus ( $0.035 \mathrm{mg} / \mathrm{kg}$ body weight) and then continuously (intravenous (IV) infusion of $0.03 \mathrm{mg} / \mathrm{kg} / \mathrm{h}$, adjusted by $0.01 \mathrm{mg} / \mathrm{kg} / \mathrm{h}$ increments until stable clinical effect). A rapid and significant reduction in subjective leg symptoms (mean latency of $13.1 \mathrm{~min}$ ), as well as PLM during wakefulness (mean latency of $5.1 \mathrm{~min}$ ) were observed. These effects were not antagonized by naloxone. Drowsiness, yawning, dizziness and nausea were the main reported side effects. However, the IV route is not recommended for apomorphine, due to crystal accumulation and hazardous IV thrombotic complications (Manson et al, 2001). Similarly, a persistent (6 months follow-up) beneficial effect of continuous subcutaneous apomorphine infusion therapy (CSAI, 120 $\mathrm{mg} /$ day) was reported in an 80-year old patient suffering from RLS and polyneuropathy, without severe side effects (Müller et al, 2014). Haba-Rubio and colleagues studied the effect of an acute low single dose of apomorphine (0.5mg) in nine patients (three men, mean age 49.5 years) with PLMS, including eight with RLS (Haba-Rubio et al, 2003). The number of PLMS decreased during the first $4 \mathrm{~h}$ following apomorphine injection. Finally, PLM and flexor reflex decreased $10 \mathrm{~min}$ after the SC administration of $3 \mathrm{mg}$ of apomorphine in a 65year old man, and completely disappeared after $30 \mathrm{~min}$ (Paradiso et al, 2002). These encouraging preliminary data support the use of apomorphine (associated with domperidone) as a second-line therapy in patients who failed to respond to conventional RLS drug regimen (Tings et al, 2005; Tribl et al, 2005; Müller et al, 2014). Similarly to PD, interindividual dose variability is reported (Tribl et al, 2005) and suggest that apomorphine treatment must be tailored to each case. In addition, as suggested by Tribl and colleagues, a "modified apomorphine test" could be considered as a diagnosis tool in RLS, using visual analogue scale and/or suggested immobilization test (Tribl et al, 2005).

\subsection{Huntington's disease}

Huntington's disease (HD) is a progressive neurodegenerative disorder characterized by motor disturbance (both hyperkinetic and hypokinetic), cognitive impairment and a wide variety of neuropsychiatric symptoms, including psychosis, anxiety and depression (McColgan \& Tabrizi, 2018). The autosomal dominantly inherited mutation on the huntingtin gene induces the production of a mutant huntingtin (mHTT) that triggers neuronal dysfunction and death (particularly of medium-sized spiny neurons), through protein aggregation,

\footnotetext{
${ }^{3}$ International Restless Legs Syndrome Rating Scale
} 


\section{ACCEPTED MANUSCRIPT}

synaptic dysfunction, mitochondrial toxicity and decreased rate of axonal transport (McColgan \& Tabrizi, 2018).

Dysfunction of central dopaminergic pathways are also described, with biphasic changes (Cepeda et al, 2014; Schwab et al, 2015): in early stages, dopamine neurotransmission is enhanced, leading to hyperkinetic movements, whereas late stages are more characterized by dopaminergic deficits (Cepeda et al, 2014). As quality of life is profoundly affected, management involves a combination of pharmacological and non-pharmacological interventions (Vitale et al, 2007; McColgan \& Tabrizi, 2018; Kieburtz et al, 2018). Promising preclinical approaches targeting excitotoxicity, mitochondrial dysfunction or inflammation have failed to show efficacy in clinical trials (Kieburtz et al, 2018) and, to date, no therapy can meaningfully control nor prevent HD devastating evolution (McColgan \& Tabrizi, 2018; Kieburtz et al, 2018). Gene-directed therapies appears to be one of the most promising approach currently investigated (Cepeda et al, 2014; Kieburtz et al, 2018). However, within a shorter timeline, targeting dopaminergic abnormalities and glutamate receptor dysfunction also seems to be a good strategy (Cepeda et al, 2014; Schwab et al, 2015). Potential dopaminergic treatments have therefore been tested in clinical trials, with variable success on choreic movements and motor function (Schwab et al, 2015). A limited number of reports on the use of apomorphine in HD are scattered through the literature. Patients' characteristics and apomorphine parameters are summarized in Table 2. Tolosa \& Sparber were the first to report that $\mathrm{SC}$ administration of at least $1 \mathrm{mg}$ of apomorphine resulted in a transient but significant reduction of abnormal involuntary movements in HD patients (N=4), within 10 to $20 \mathrm{~min}$ and for up to $80 \mathrm{~min}$ (Tolosa \& Sparber, 1974). If these results were in contrast with a previous study from Lal et al, 1973 (where acute injections of $1 \mathrm{mg}$ of apomorphine were deprived of any effect in two HD patients), they were reproduced a few years later (Table 2) (Corsini et al, 1978; Caraceni et al, 1980; Bentivoglio et al, 1992; Albanese et al, 1995). The amplitude and frequency of choreic movements appears to be reduced in a dose-related way (Corsini et al, 1978; Caraceni et al, 1980), and the transiency of the antichoreic effect reflects the short half-life of apomorphine (Vitale et al, 2007; Auffret et al, 2018b). To be noted, apomorphine antichoreic effect could be antagonized partially by $2 \mathrm{mg}$ of haloperidol and completely by $100 \mathrm{mg}$ of sulpiride, hence supporting the hypothesis that it is mediated by dopaminergic receptors (Tolosa \& Sparber, 1974; Corsini et al, 1978). It has been suggested that the effect of apomorphine on abnormal involuntary movements was partly due to its sedative and hypnotic action (Caraceni et al, 1980; Albanese et al, 1995), but this seems unlikely (Tolosa \& Sparber, 1974; Corsini et al, 1978; Sanberg et al, 1979). Based on their results, Albanese and collaborators suggested that HD patients could benefit from chronic and tailored treatment with dopaminergic agonists (Albanese et al, 1995). This hypothesis was tested in a pilot, single center, double blind, randomized, crossover and controlled versus placebo trial 


\section{ACCEPTED MANUSCRIPT}

(Vitale et al, 2007). Nine unrelated consecutive HD patients underwent an apomorphine test to determine the most efficient dose; four patients were withdrawn from the study due to lack $(\mathrm{N}=2)$ or worsening $(\mathrm{N}=2)$ of response (Vitale et al, 2007). Compared to placebo, CSAI (5 day-time regimen, $12 \mathrm{~h} / \mathrm{day}, 10$ to $20 \mu \mathrm{g} / \mathrm{kg}$ body weight) produced a significant and sustained benefit on choreic symptoms, with a very satisfying safety and tolerability profile (Vitale et al, 2007). Taken together, these data suggest that apomorphine is of interest in HD, after preliminary screening to detect non-responders. It is quite surprising that large studies exploring the longterm efficacy of CSAI in HD have not been conducted yet.

Table 2: Summary of the results of the clinical trials on apomorphine use in Huntington's disease.

AIM: abnormal involuntary movements; AIMS: Abnormal Involuntary Movement Scale; F: female;

GH: growth hormone; M: male; N/A: not available; TID: three times a day; UHDRS: Unified

Huntington's Disease Rating Scale

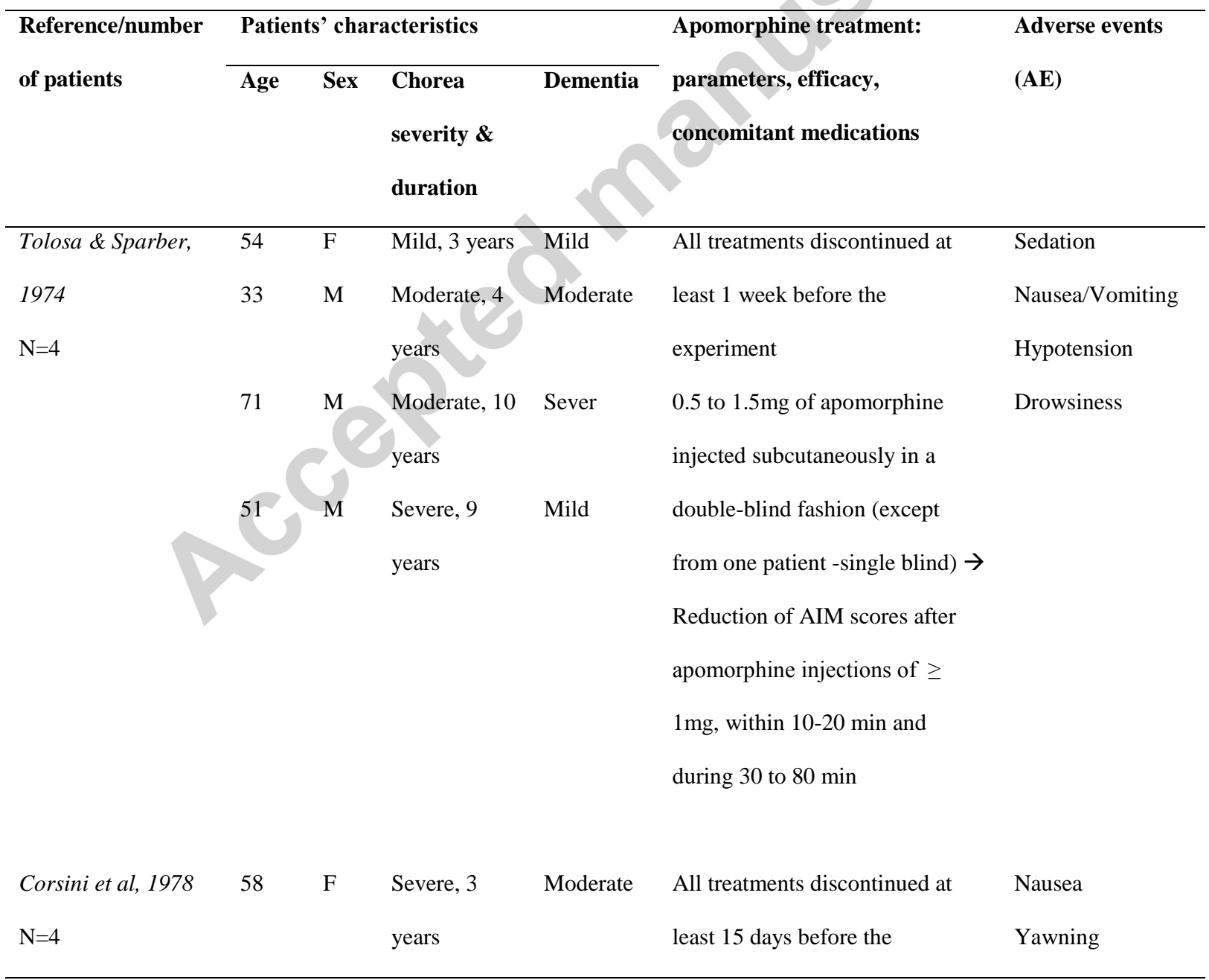




\begin{tabular}{|c|c|c|c|c|c|c|}
\hline & & & ACCEEP' & 름 $N$ & IUSCRIPT & \\
\hline & 52 & $\mathrm{M}$ & Severe, 7 & Severe & experiment & No sedation \\
\hline & & & years & & 1 to $4 \mathrm{mg}$ of apomorphine & No sleepiness \\
\hline & 38 & M & Mild, 4 years & Mild & injected intramuscularly in a & \\
\hline & 42 & $\mathrm{~F}$ & Mild, 3 years & Mild & double-bling Latin square design & \\
\hline & & & & & $\rightarrow$ Reduction of AIM scores by & \\
\hline & & & & & 40 to $55 \%$ at the doses of $1-2 \mathrm{mg}$ & \\
\hline & & & & & and by $75-85 \%$ at the doses of $3-$ & \\
\hline & & & & & $4 \mathrm{mg}$ & \\
\hline & & & & & Reduction of both amplitude and & \\
\hline & & & & & frequency of the choreic & \\
\hline & & & & & movements in a dose-related & \\
\hline Caraceni et al, 1980 & 41 & M & Mild, 5 years & N/A & All treatments discontinued & Nausea/vomiting \\
\hline $\mathrm{N}=4$ & 27 & $\mathrm{~F}$ & Severe, 6 & N/A & before the experiment (no time- & $(\mathrm{N}=4)$ \\
\hline & & & years & & lapse given) & Sleepiness $(\mathrm{N}=4)$ \\
\hline & 51 & M & Moderate, 4 & N/A & $1 \mathrm{mg}$ of apomorphine injected & Yawning (N=4) \\
\hline & & & years & & subcutaneously $\rightarrow$ significant & Hypotension \\
\hline & 50 & $\mathrm{~F}$ & Moderate, 10 & N/A & decrease in hyperkinesia (43 to & $(\mathrm{N}=4)$ \\
\hline & & & years & & $75 \%$ change) at 10 and $20 \mathrm{~min}$ & Bradycardia $(\mathrm{N}=4)$ \\
\hline & & & & & Increase in GH plasma levels & \\
\hline Bentivoglio et al, & N/A & N/A & N/A & N/A & Domperidone $20 \mathrm{mg}$ tid & Yawning \\
\hline 1992 & & & & & Single subcutaneous injection of & Sleepiness \\
\hline$N=6$ & & & & & apomorphine $(0.05 \mathrm{mg} / \mathrm{kg}) \rightarrow$ & Nausea/emesis \\
\hline & 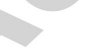 & & & & Reduction of choreic & Hypotension \\
\hline & & & & & movements, with a mean latency & \\
\hline & & & & & effect of $24 \pm 3.67 \mathrm{~min}$ and a & \\
\hline & & & & & mean benefit duration of $60 \pm$ & \\
\hline & & & & & $4.74 \mathrm{~min}$ & \\
\hline Albanese et al, 1995 & 42.33 & $4 \mathrm{M}$ & Present, 4.44 & N/A & Neuroleptic drugs discontinued > & Yawning (N=9) \\
\hline $\mathrm{N}=9$ & \pm & $5 \mathrm{~F}$ & \pm 0.88 years & & 3 months before the experiment & Mild nausea \\
\hline & 4.07 & & & & Domperidone (20mg tid) started & $(\mathrm{N}=6)$ \\
\hline
\end{tabular}




\section{ACCEPTED MANUSCRIPT}

(29-

61)

\begin{tabular}{|c|c|c|c|}
\hline Vitale et al, 2007 & 50 & M & Present, 5 \\
\hline \multirow[t]{9}{*}{$\mathrm{N}=9$} & & & years \\
\hline & 50 & $\mathrm{~F}$ & Present, 6 \\
\hline & & & years \\
\hline & 33 & $\mathrm{~F}$ & Present, 5 \\
\hline & & & years \\
\hline & 43 & M & Present, 6 \\
\hline & & & years \\
\hline & 32 & F & Present, 5 \\
\hline & & & \\
\hline
\end{tabular}

1.5 or $3 \mathrm{mg}$ of apomorphine

injected subcutaneously in a

double-blind design $\rightarrow$

Reduction of chorea \& motor

impersistence scores by $38.54 \%$

at the dose of $1.5 \mathrm{mg}$ and of

chorea scores (only) by $30.41 \%$

after $3 \mathrm{mg}$

Crossover design: 5 days of

apomorphine/placebo, 2 days

washout and 5 days of the

alternative treatment.

Apomorphine administered as a

continuous infusion of $10 \mu \mathrm{g} / \mathrm{kg}$

bw (except 1 patient, with APO

$20 \mu \mathrm{g} / \mathrm{kg}$ bw) $12 \mathrm{~h} /$ day $\rightarrow$

Significant decrease in UHDRS

(mean decrease: $42.5 \pm 5.3 \%$ ) \&

AIMS (mean decrease: $34.4 \pm$

$14.6 \%)$ scores.
Vomiting (N=2)

Drowsiness $(\mathrm{N}=3)$

Orthostatic

hypotension $(\mathrm{N}=1)$
Transient

drowsiness at

infusion initiation

No AE during the

treatment 


\section{ACCEPTED MANUSCRIPT}

\subsection{Disorders of consciousness}

Though still incompletely understood, the neuropathology of traumatic brain injury (TBI) involve direct anatomical damage (primary injury) and disruption of both functional electrical and chemical transmission (Pistoia et al, 2010; Chen et al, 2017). This "secondary phase", evolving for weeks and even months after the mechanical injury (diffuse axonal injury) is characterized by persistent neuroinflammation, oxidative stress, neurotrophic factors changes and apoptosis of neurons and glia (Chen et al, 2017). TBI can induce long-term disorders of consciousness (DOC), including vegetative state (VS) and minimally conscious state (MCS), characterized by arousal but lack of awareness (Pistoia et al, 2010). VS and MCS (to a lesser extent) stem from a disconnection of several cortical networks associated with functional changes at the neurotransmitter level (Pistoia et al, 2010; Chen et al, 2017). More precisely, alterations in monoamine signaling and dopaminergic abnormalities (in the nigrostriatal and mesolimbic systems) are documented in a significant proportion of patients suffering from moderate to severe TBI (Fridman et al, 2010; Chen et al, 2017). Therapeutic goals (improvement of awareness levels) and clinical recovery (recovery of consciousness) involve the functional restoration of disrupted networks (Chen et al, 2017; Pistoia et al, 2010). Dopaminergic-targeted strategies are common in rehabilitative programs (Chen et al, 2017) and several studies have sporadically shown that levodopa, pramipexole, bromocriptine or amantadine can help regain consciousness and accelerate recovery, particularly for patients showing signs of parkinsonism (Pistoia et al, 2010; Fridman et al, 2010). Being a direct nonspecific dopaminergic agonist with potential neurorecovery properties and parenteral administration, apomorphine appears theoretically of great interest in DOC. To date, only eight cases (4 males, aged 22-41 years) of functional recovery from VS $(\mathrm{N}=6)$ or MCS $(\mathrm{N}=2)$ with apomorphine have been documented, in an open-label pilot study (Fridman et al, 2009; 2010). Before apomorphine initiation, patients were administered domperidone (20 mg three times a day) to circumvent peripheral side effects. Apomorphine was initiated at an infusion rate of $2 \mathrm{mg} / \mathrm{h}$ for $12 \mathrm{~h}$ per day, up to $8 \mathrm{mg} / \mathrm{h}$ for 12 to $16 \mathrm{~h}$ per day. Levels of consciousness were objectified through the Coma Near-Coma Scale (CNCS) and the Disability Rating Scale (DRS). Results are summarized in Table 3. All patients began to respond to commands after initiation of apomorphine treatment, within 10 days $(\mathrm{N}=4)$ or above 4 weeks $(\mathrm{N}=4)(1-62$ days). All surviving patients $(\mathrm{N}=7)$ reached a CNCS of 0 within a year and returned home, with moderate disability or good recovery. Four patients reached an independent walking ability and two regained full independence. Side effects were mild to moderate and included local reactions, sedation, agitation, drowsiness, nausea and vomiting (Fridman et al, 2009; 2010). Some patients experienced dyskinesia at the highest dose of apomorphine ( $8 \mathrm{mg} / \mathrm{h})$ (Fridman et al, 2009; 2010). 
Table 3: Results from Fridman's studies, exploring the efficacy of apomorphine in vegetative and minimally conscious states patients due to sever traumatic brain injury (Fridman et al, 2009, 2010). APO: apomorphine;

CNCS: Coma Near-Coma Scale; DRS: Disability Rating Scale; F: female; M: male; MCS: minimally conscious state; TBI: traumatic brain injury; VS: vegetative state

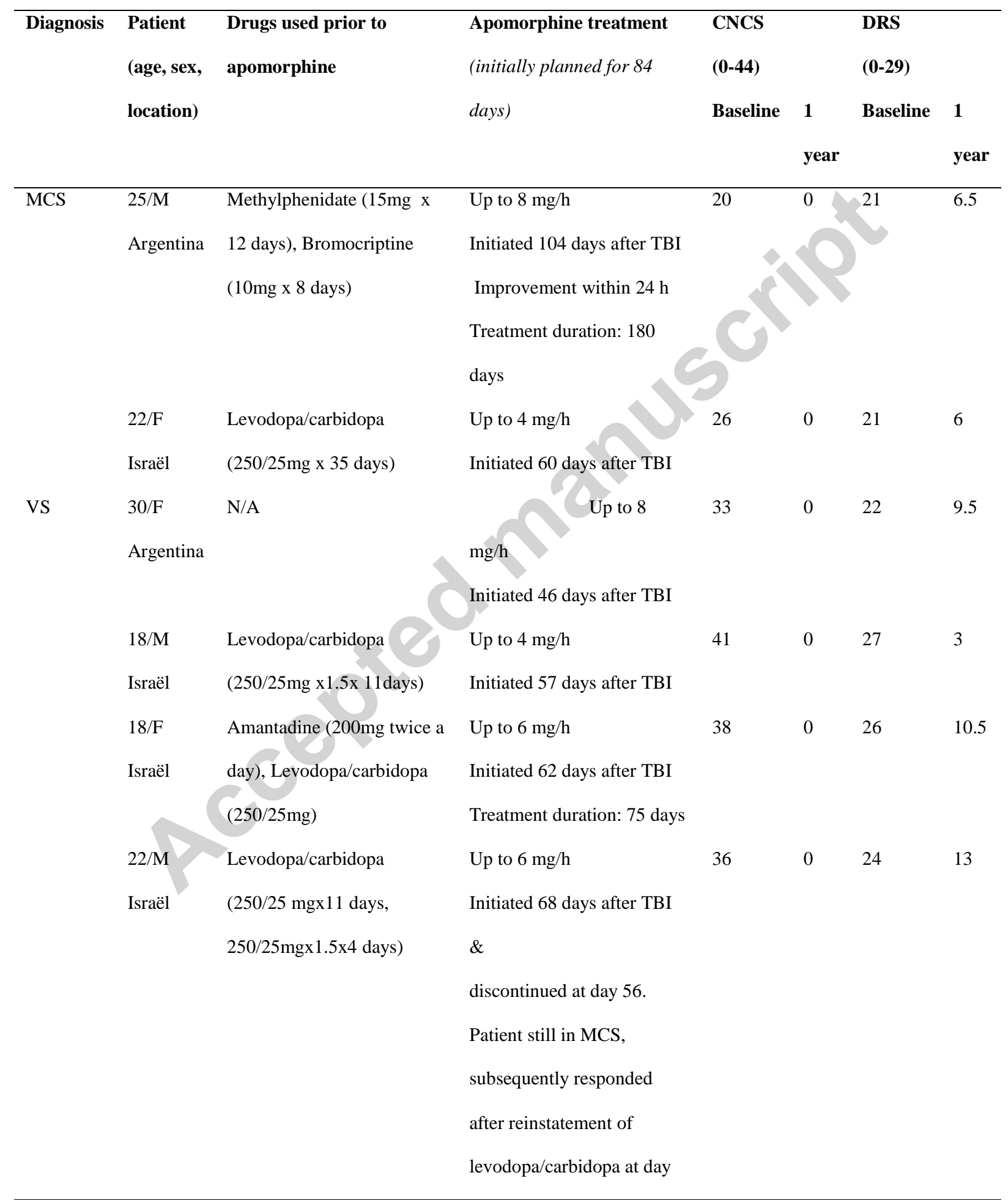




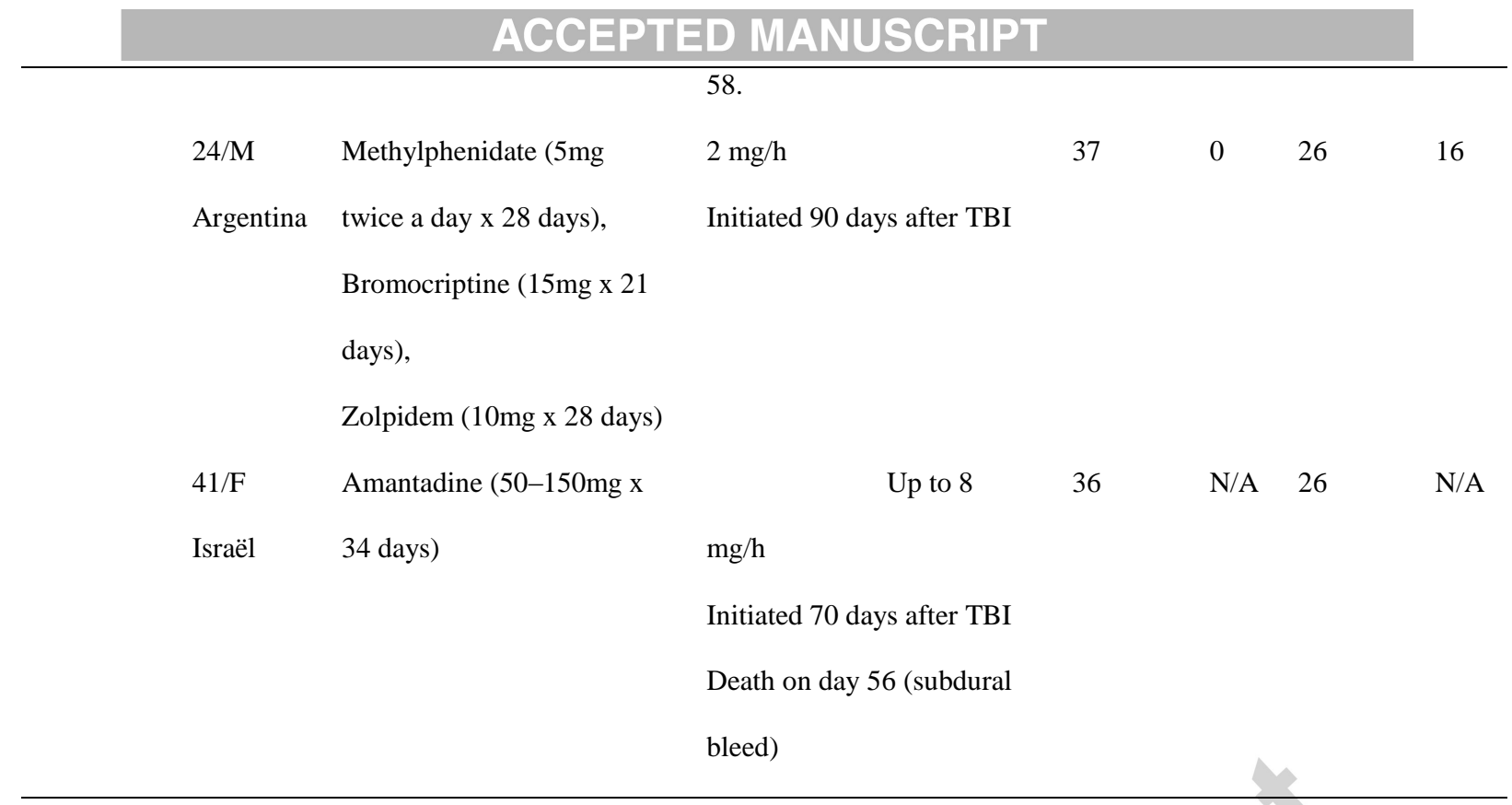




\section{ACCEPTED MANUSCRIPT}

Of major interest, improvements were maintained in all patients after apomorphine discontinuation. CSAI therefore seems to be a feasible and safe way to achieve a sustained functional recovery (Fridman et al, 2009; 2010). To be noted, seven patients had been previously and unsuccessfully treated with dopaminergic stimulants, which points out towards non-dopaminergic mechanisms, like neurotrophic factors induction or neurorecovery properties (Guo et al, 2002) - but that remains to be proven.

Nevertheless, these results are not based on a rigorous double-blind placebo-controlled design and are only confined to a few subjects. Larger samples are needed, especially since patients' heterogeneity regarding injuries, extent of lesion and management, make interpretation difficult (Pistoia et al, 2010; Chen et al, 2017). A prospective, multi-center, randomized, double-blind, placebo-controlled study of the safety and efficacy of apomorphine hydrochloride (NH001, up to $6 \mathrm{mg} / \mathrm{h}$ for $12 \mathrm{~h}$ a day) in VS and MCS following TBI was launched in 2010 and expected to enroll 76 patients (ClinicalTrials.gov Identifier: NCT00761228), but it is currently suspended ${ }^{4}$. Further studies involving neuroimaging and/or electroencephalography source connectivity (Hassan et al, 2014) should be conducted to confirm these preliminary findings and to assert which type(s) of DOC patients are more likely to benefit from apomorphine therapy.

\subsection{Amyotrophic lateral sclerosis}

Amyotrophic lateral sclerosis (ALS) is a rare (2 to 3 cases per 100000 individuals) progressive neurodegenerative disease, affecting upper and lower motor neurons and leading to loss of muscle function and paralysis (Hardiman et al, 2017). Cognitive and behavioral impairment are often associated with motor dysfunction (Hardiman et al, 2017). The etiology of ALS remains poorly understood but an association between genetic risk and environmental factors is suspected (Hardiman et al, 2017). The neuropathological hallmark of ALS is the presence of protein aggregates in motor neurons, either TDP43 or misfolded SOD-1 (superoxide dismutase) (Hardiman et al, 2017). Neuroinflammation, mitochondrial dysfunction, excitotoxicity and oligodendrocytes degeneration are also observed (Hardiman et al, 2017). SOD-1-related toxicity include hyperexcitability, glial dysfunction and oxidative stress (Da Costa et al, 2014; Hardiman et al, 2017). Management strategies mostly rely on developing disease-modifying therapy and symptomatic treatment (Hardiman et al, 2017), and effective antioxidant therapies are not available yet for ALS (Mead et al, 2013). Future treatments are expected to target specific disease subtypes, through a personalized approach (Hardiman et al, 2017).

\footnotetext{
${ }^{4}$ Last Update Posted on ClinicalTrials.gov: March 31, 2017
} 


\section{ACCEPTED MANUSCRIPT}

An orphan drug designation for S-(+)-apomorphine was granted in February 2012 by the European Medicines regulatory agency (EU/3/12/954 ${ }^{5}$ to the University of Sheffield (United Kingdom) for the treatment of ALS. Recent preclinical data (Mead et al, 2013; Da Costa et al, 2014) have indeed shown that S-(+)apomorphine is a CNS-penetrant Nrf2 activator (Mead et al, 2013) and a potential antioxidant both in vitro (Sam \& Verbeke, 1995; Gassen et al, 1998) and in vivo (mice, zebrafish embryos) (Mead et al, 2013; Da Costa et al, 2014). S-(+)-apomorphine reduces pathological oxidative stress and improve survival of fibroblasts from both sporadic and familial ALS patients who harbor SOD1 mutations (Mead et al, 2013). In addition, S-(+)apomorphine significantly attenuates motor dysfunction in the G93A SOD1 transgenic mouse model of ALS (though without improving survival) and increases survival in the T70I sod1 zebrafish model (G93Ros10-Sh4 line) (Mead et al, 2013; Da Costa et al, 2014). Data are still scarce and, at the time of our writing, clinical trials with S-(+)-apomorphine in patients with ALS have not started. Nonetheless, these preliminary results are encouraging and call for further investigation. To be noted, R-(-)-apomorphine is a glutaminase inhibitor (Thomas et al, 2013); it would be interesting to investigate whether S-(+)-apomorphine has the same activity, and acts on glutamate-induced excitotoxicity, a known component of corticomotor neuronal hyperexcitability (Yuan et al, 2017).

\subsection{Alzheimer's disease}

Alzheimer's disease (AD) is a chronic and progressive disease characterized by central (dementia), peripheral (cardiovascular, hepatic, respiratory disorders) and systemic (disorders of systemic immunity, microbiota disturbance, systemic inflammation) abnormalities (Wang et al, 2017). Either sporadic or genetic, AD is currently untreatable and effective treatments (either preventive or curative) are lacking, despite hundreds of clinical trials (Ohyagi, 2012; Wang et al, 2017; Nakamura et al, 2017). Current pharmacological management is based on cognition-enhancing agents (cholinesterase inhibitors and NMDA receptor antagonist), with limited efficacy (Masters et al, 2015). The two major hallmarks of AD are senile plaques, caused by abnormal amyloid- $\beta$ (A $\beta$ ) metabolism, and neurofibrillary tangles (aggregates of hyperphosphorylated tau proteins), which spread through the brain as the disease progresses (Masters et al, 2015; Wang et al, 2017). Other mechanisms are also involved in $\mathrm{AD}$ pathogenesis, including but not limited to oxidative stress (enhancing protein aggregation), (micro)glial changes and reactivity, increased insulin resistance and neuroinflammation (Himeno et al, 2011; Ohyagi, 2012; Wang et al, 2017; Nakamura et al, 2017). For the last few years, A $\beta$ has been a fertile area of

\footnotetext{
${ }^{5}$ http://www.ema.europa.eu/ema/index.jsp?curl=pages/medicines/human/orphans/2012/03/human orphan
} 001028.jsp\&mid=WCOb01ac058001d12b 


\section{ACCEPTED MANUSCRIPT}

research, owing to the fact that an imbalance between the production and elimination of A $\beta$ is found very early in the disease and precedes the occurrence of neurofibrillary tangles (Lashuel et al, 2002; Ohyagi, 2012; Masters et al, 2015; Wang et al, 2017). A $\beta$ is divided into several types, including A $\beta 40$ but also A $\beta 42$, considered as an important therapeutic target, due to its neurotoxicity and early appearance (Himeno et al, 2011; Ohyagi, 2012; Nakamura et al, 2017). R-(-)-apomorphine and apomorphine derivatives (R-(-)-norapomorphine) interfere with the mechanisms of fibrillization (A $\beta 1-40)$ and/or oligomerization (A $\beta 42)$ (Lashuel et al, 2002; Hanaki et al, 2018). The hydrophobic nature of apomorphine may increase its affinity for binding $A \beta$, but other mechanisms may account for this activity (Steele \& Gandy, 2011), including the autoxidation of the 10,11-dihidroxy substitutions of the phenol ring (Lashuel et al, 2002; Hanaki et al, 2018). In addition, R-(-)-apomorphine enhances degradation of intracellular A $\beta 42$ in human neuroblastoma cells (SH-SY5Y) (Hanaki et al, 2018) and in the familial triple transgenic AD mouse model (3xTg-AD mice) (Himeno et al, 2011). The promotion of intracellular $A \beta$ degradation seems to be mediated through $A \beta$-degrading enzymes, proteasome and insulindegrading enzyme (IDE) (Himeno et al, 2011). Apomorphine also decreased hyperphosphorylated tau proteins levels and protected neurons from oxidative stress in the same AD mice model (Himeno et al, 2011). Apomorphine was also shown to reduce oxidative stress in $3 x \mathrm{Tg}-\mathrm{AD}$ mice, as well as in a human neuroblastoma cell line (SH-SY5Y), by targeting p53-related apoptosis and enhancing glutathione peroxidase (GPx) activity, among other possible mechanisms (Himeno et al, 2011; Ma et al, 2011). These effects were not limited to intracellular changes: when administered subcutaneously to 3xTg-AD mice once a week for one month (5-20 $\mathrm{mg} / \mathrm{kg}$ ), apomorphine even improved short-term memory function, the best results being obtained with a dose of $5 \mathrm{mg} / \mathrm{kg}$ (Himeno et al, 2011). Very recently, another study showed that 1-month SC injections of R-(-)apomorphine to $3 \mathrm{xTg}-\mathrm{AD}$ mice (6 and 12 months of age) decreased brain insulin resistance (upregulation of insulin-degrading enzyme) and improved spatial memory (Nakamura et al, 2017). These preliminary results (apparent anti-amyloidogenic, neuroprotective and antioxidant properties) suggest that apomorphine (or apomorphine derivatives, Lashuel et al, 2002; Nabavi et al, 2018) therapy could be beneficial in AD (Lashuel et al, 2002; Himeno et al, 2011), either early in the disease (Lashuel et al, 2002; Himeno et al, 2011) or in advanced stages (Nakamura et al, 2017). Another argument is that antemortem apomorphine exposure was found to significantly reduce $A \beta$ deposition (diffuse and total plaque load) in the brain of cognitively normal parkinsonian donors $(\mathrm{N}=19)$, compared to those who were never exposed to apomorphine $(\mathrm{N}=17)$ (Yarnall et al, 2015). In contrast to AD murine model (Himeno et al, 2011) however, no difference was observed after apomorphine exposure in tau aggregation in the PD brains (Yarnall et al, 2015). 


\section{ACCEPTED MANUSCRIPT}

Further work is needed to determine whether apomorphine has a modifying effect on $A \beta$ deposition in AD, and to assess the best time for initiating therapy. A small-sized $(\mathrm{N}=5)$ pilot clinical trial exploring the efficacy of a weekly injection of Apokyn ${ }^{\circledR}$ in $\mathrm{AD}$ patients apparently showed that memory function improved after 3 months of treatment, which is promising (Nakamura et al, 2017). At the time of our writing however, no detailed data on this trial were available.

\section{Apomorphine and sexual disorders}

\subsection{Men}

Erectile dysfunction (ED) is the most common sexual complaint in men (Albersen et al, 2010). This complex and multifactorial disorder (Costa, 2003) is defined as a "persistent inability to achieve and/or maintain an erection sufficient for satisfactory sexual intercourse" (NIH Consensus Conference, 1993). As penile erection is regulated both centrally (dopamine and melanocortin-receptors) and peripherally (nitric oxide -NO- and stimulation of smooth muscle relaxation), numerous factors can contribute to ED: endothelial dysfunction (vascular disorders), systemic, psychological and/or neurological disorders, hormonal factors, advancing age and/or iatrogenic causes (MacLennan et al, 2004; Afif-Abdo et al, 2008; Albersen et al, 2010; Mohee et al, 2012).

In the beginning of the 1970's, preclinical experiments showed that apomorphine reliably induces several behavioral changes (genital grooming, yawning) and genital responses (penile erections, mounting, intromission and ejaculation) in male rats (Butcher et al, 1969; Tagliamonte et al 1974; Heaton et al, 1991; Melis et al, 1994). The same effects were reported in "sexually sluggish" rats (Tagliamonte et al, 1974) and in castrated rats in the presence or absence of testosterone, by some authors (Malmnäs, 1977; Scaletta \& Hull, 1990) whereas others did not reproduce the same results (Heaton \& Varrin, 1994). These apomorphine-induced sexual effects were partially antagonized by haloperidol, pointing out towards dopaminergic pathways (Tagliamonte et al, 1974). Since then, apomorphine was shown to act through a central mechanism (Matsumoto et al, 2005) and a potential additional spinal site of action (Ishizuka et al, 2002). Advancing age reduces apomorphine efficacy in rats, presumably through an alteration of central dopaminergic pathways (Varrin \& Heaton, 1992). Around the same time, clinical trials led to the serendipitous discovery that SC injections of apomorphine (1-4mg) induced spontaneous penile erection in men (Lal \& De La Vega, 1975). In men, these effects are mediated by a direct activation of the hypothalamic dopaminergic pathways, the central neural paths leading to vasodilatation (Melis et al, 1987, 1994; Lal et al, 1989; Tarcan et al, 2000; Maclennan et al, 2006; Riley et al, 2010), and a potential 


\section{ACCEPTED MANUSCRIPT}

peripheral relaxant direct effect on the corpus cavernosum (d'Emmanuele di Villa Bianca et al, 2005). A functional magnetic resonance imaging placebo-controlled study provided an in vivo demonstration that apomorphine modulates cortical and subcortical brain structures in psychogenic ED patients, with a downregulation of frontal limbic areas showing increased activity (Montorsi et al, 2003a). As shown in animals, an additional action at the level of the spinal cord has also been reported in humans (Pehek et al, 1989; Giuliano \& Allard, 2002). In the beginning of the 2000's, Ixense ${ }^{\circledR}$ (Takeda, 2001) and Uprima ${ }^{\circledR}$ (Abbott Laboratories, 2001) were commercialized for impotence/erectile dysfunction as the first treatment for ED with a central mode of action (sublingual apomorphine 2 and $3 \mathrm{mg}$ ). Erection usually occurred within $20 \mathrm{~min}$ (Altwein \& Keuler, 2001) with an overall good tolerability. Adverse events were usually mild to moderate: headache, nausea/vomiting, dizziness, yawning, hypotension/vasovagal-type symptoms, chest pain, mouth ulceration, taste perversion or stomatitis (the latter being due to the sublingual administration) (Altwein \& Keuler, 2001; Giuliano \& Allard, 2002; Montorsi, 2003b; Perimenis et al, 2004; Mohee et al, 2012). Hypersensitivity reactions (facial edema) or syncope occurred very rarely (MacLennan et al, 2004; Afif-Abdo et al, 2008; Altwein \& Keuler, 2001). Despite a promising entry (fast absorption and rapid onset of action, favorable tolerability and safety profile especially in patients receiving nitrates -Morales, 2001; Heaton, 2001; Perimenis et al, 2004), Ixense® and Uprima ${ }^{\circledR}$ were soon to be discontinued (respectively in 2004 and 2006), facing the competition of the phosphodiesterase type 5 inhibitors (PDE5I) family (Afif-Abdo et al, 2008). Compared to sildenafil, apomorphine use was associated with lower efficacy, lower satisfaction rates, and troublesome adverse events (Maclennan et al, 2006; Porst et al, 2007; Albersen et al, 2010). A postmarketing surveillance study led in England, within an observational cohort of more than 10000 patients from general medical practice, showed that $40 \%$ of the patients had stopped apomorphine at the end of the first month and more than $70 \%$ stopped using apomorphine after 6 months, the main reason being that it was "not effective" (MacLennan et al, 2004).

However, several points are to be considered. Firstly, as a central initiator, apomorphine is not an adequate option for arteriogenic ED (Afif-Abdo et al, 2008) because it requires erectile potential (Heaton et al, 1995). It is, however, a good option in cases of non-arteriogenic ED, psychogenic ED, and contraindication to sildenafil (Morales, 2001; Perimenis et al, 2004). One can therefore wonder if the 10000 patients of the Maclennan's study were correctly screened at first (distinction between types of ED and distinction between ED and problems with libido, orgasm or ejaculation) and/or if apomorphine was correctly used, the tablets being ineffective if swallowed (MacLennan et al, 2004). To be noted, a small study ( $\mathrm{N}=22)$ on patients with chronic spinal cord injury and erectile dysfunction showed overall low rates of response (Strebel et al, 2003). Secondly, many 


\section{ACCEPTED MANUSCRIPT}

studies were carried out with an open design and failed to take into account confounding factors like apomorphine dose and frequency of administration, patient age, ED etiology (arteriogenic $v s$ non-arteriogenic), coexisting disease and/or concomitant treatments (MacLennan et al, 2004; Afif-Abdo et al, 2008). Reasons making patients poor responders to apomorphine were also not investigated. Finally, the "on demand" scheme of administration (based on sildenafil), might not be the best for apomorphine. Sequential administration (Heaton et al, 2002) and a daily regimen (Caruso et al, 2003) were indeed shown to be more effective than the "taken-as needed" scheme.

The multifactorial nature of ED requires a multidimensional approach (Costa et al, 2001; Heaton, 2001). A synergistic approach, combining centrally acting drugs with peripherally acting drugs like sildenafil (Park et al, 2004; Huang et al, 2008; Solayman et al, 2012) or other vasoactive drugs (Lammers et al, 2002) could be advised, and accompanied by psychosexual counselling (Costa et al, 2001). In conscious rabbits, apomorphine enhances the sildenafil-induced erection without causing an additional decrease in blood pressure (Park et al, 2004). This approach should be tested in human, with caution regarding potential additional hypotensive effect.

Furthermore, sublingual apomorphine could represent a good alternative pharmacotherapeutic option for impotent patients also suffering from neurodegenerative diseases, like PD, multiple sclerosis atrophy (MSA) or even multiple sclerosis (MS) (O’Sullivan \& Hughes, 1998; DasGupta \& Fowler, 2003; Flabeau et al 2010 ; Bronner \& Vodušek, 2011; Perez-Lloret et al, 2015). Surprisingly (particularly for PD), its use in these indications has not been assessed yet, despite being advised by O'Sullivan \& Hughes (1998).

When considering a customized approach (Heaton, 2001), apomorphine remains relevant in ED, particularly for a subset of patients (Mohee et al, 2012), where it can even represent a first-line oral therapy (Heaton, 2001; Montorsi, 2003b; Perimenis et al, 2004; Albersen et al, 2010). A new inhalation device administering lower doses of apomorphine (VR004) was developed at the end of the 2000's and seemed rather promising (Riley et al, 2010), but its development for male sexual dysfunction has been suspended, apparently due to lack of partners (Albersen et al, 2010). Research efforts and clinical trials targeting subgroups of ED and neurodegenerative patients are therefore needed, as sexual disorders significantly contribute to lower the quality of life of both patients and spouses (Porst et al, 2007).

\subsection{Women}

Following the discovery that apomorphine could modify the sexual response in male rats, experiments were conducted in female rats, demonstrating that dopamine is also involved in the regulation of female sexual 


\section{ACCEPTED MANUSCRIPT}

behavior (Hamburger-Bar \& Rigter, 1975; Foreman \& Moss, 1979). Evidence currently suggest that similar neural substrates (hypothalamic areas) and pathways mediate the female and male sexual behaviors (Bechara et al, 2004). Female sexual response depends on hormonal factors (that vary throughout the reproductive cycle) and is characterized by hemodynamic changes (clitoral engorgement and vaginal vasocongestion) involving NO, sympathetic, parasympathetic and noradrenergic pathways (Beharry et al, 2003; Bechara et al, 2004). Apomorphine (acute SC injection, $0.25 \mathrm{mg} / \mathrm{kg}$ ) increases sexual behavior (lordosis response) in oestrogen and oestrogen+progesterone-primed spayed female rats, this facilitatory effect lasting up to $48 \mathrm{~h}$ after administration (Hamburger-Bar \& Rigter, 1975; Foreman \& Moss, 1979). In anesthetized rabbits, apomorphine (0.1 and $0.2 \mathrm{mg} / \mathrm{kg}, \mathrm{IV}$ ) increases nerve-stimulated (but not basal) clitoral intracavernosal and vaginal wall arterial inflow, hence increasing engorgement (Tarcan et al, 2000). These effects are accompanied with a significant decrease in diastolic arterial pressure (Tarcan et al, 2000). Greater concentrations are less effective and produce adverse effects (Tarcan et al, 2000). In ovariectomized Long-Evans female rats, the administration of low doses of apomorphine $(80 \mu \mathrm{g} / \mathrm{kg}, \mathrm{SC})$ to the medial preoptic areas induces a significant increase in appetitive sexual behaviors (solicitations, hops and/or darts) (Graham \& Pfaus, 2008). Another experiment on female Wistar rats showed that the magnitude of apomorphine-induced sexual changes (genital grooming, genital engorgement) depends on the stage of the estrous cycle (Beharry et al, 2003). Taken together, these preclinical data (patterned behavioral sexual response and genital changes) suggest that apomorphine may play a role in female sexual disorders, through a modulation of hemodynamic mechanism and dopaminergic pathways, in a rapid and transient way.

Contrary to erectile dysfunction, apomorphine effect has been poorly explored in female sexual dysfunction (FSD) (Beharry et al, 2003; Bechara et al, 2004). They are four types of FSD: sexual pain disorder (dyspareunia, vaginismus), hypoactive sexual desire disorder (lack of mental excitement and physical genital congestion), sexual arousal disorder and orgasmic disorder (Beharry et al, 2003; Buster, 2013). The pathophysiology remains unclear but is probably multifactorial, with a combination of organic (vascular, neurological, hormonal) and underlying psychological disorders (Beharry et al, 2003; Bechara et al, 2004; Caruso et al, 2004). Highly prevalent, FSD affects at least a third of women, with various degrees of severity (Beharry et al, 2003; Bechara et al, 2004), impairing life quality and interpersonal relationships (Bechara et al, 2004). In a prospective, doubleblind and randomized cross-over study on women with orgasmic sexual dysfunction (N=24, age $32 \pm 9.69$ years), a single administration of sublingual apomorphine (3mg) was shown to induce both objective (clitoral hemodynamic changes) and subjective (arousal and lubrication) changes in the sexual arousal phase, compared 


\section{ACCEPTED MANUSCRIPT}

to placebo (Bechara et al, 2004). By contrast, differences between placebo and apomorphine on orgasm were not statistically significant, but confounding factors due to a research situation might be an explanation (Bechara et al, 2004). In another study, apomorphine (2-3mg sublingually) efficacy was assessed in premenopausal women ( $\mathrm{N}=62,26-45$ years old) affected by sexual arousal disorder, either in an "as required" or daily use regimen (Bechara et al, 2004). The daily regimen was more effective than the "taken-as needed" (Caruso et al, 2004) in increasing sexual desire, orgasm, enjoyment and satisfaction (Caruso et al, 2004), which echoes previously mentioned results from ED studies (Caruso et al, 2003). Reported adverse events during apomorphine treatment were usually mild to moderate (nausea, vomiting, dizziness and headache) and affected a small proportion of the studied population (Bechara et al, 2004; Bechara et al, 2004). To be noted, the MacLennan's study cohort showed that apomorphine SL (2-3mg) was prescribed to 8 women (median age 50 years old) for decreased libido, pain and/or sexual arousal phase dysfunction (Maclennan et al, 2004). Unfortunately, no detailed data regarding patients' profile, adverse events or apomorphine efficacy are available. It would be interesting to lead a retrospective study (2001-2006) and to collect clinical data from these uncommon prescriptions of Uprima ${ }^{\circledR}$ and Ixense $\AA$ in the countries where they were available.

Although data are scarce, they do suggest that apomorphine may improve some aspects of FSD. Future work is needed in this niche area, with longitudinal prospective study exploring the efficacy of apomorphine in premenopausal and postmenopausal women, as well as in types of FSD other than sexual arousal disorders and orgasmic disorders.

\section{Apomorphine and Neuroleptic (-Like) Malignant Syndrome}

Neuroleptic malignant syndrome (NMS) is a rare, acute, severe and potentially lethal idiosyncrasic reaction to antipsychotics, mainly neuroleptics (Wang \& Hsieh, 2001; Gambassi et al, 2006). It is usually characterized by rigidity, hyperthermia, altered mental status and autonomic dysfunction, typically associated with elevated serum creatinine phosphokinase levels and white blood cell count (Wang \& Hsieh, 2001; Gambassi et al, 2006; Oruch et al, 2017). The malignant syndrome in PD or "neuroleptic-like malignant syndrome" (NLMS) is quite similar to NMS: potentially fatal, with fever, altered levels of consciousness, muscle tone increase, autonomic disturbance and elevated serum creatine kinase levels (Ikebe et al, 2003). It is usually caused by an abrupt-reduction or cessation in antiparkinsonian drugs (levodopa or dopaminergic agonists), but it can also be precipitated by intercurrent infections, hot weather or dehydration (Wang \& Hsieh, 2001; Ikebe et al, 2003; Douglas \& Morris, 2006; Gambassi et al, 2006). 


\section{ACCEPTED MANUSCRIPT}

The pathophysiology of NMS and NLMS remains unclear. In NMS, the commonly accepted model is an abrupt blockade of dopamine receptors, particularly in the nigrostriatal and hypothalamic pathways (Wang \& Hsieh, 2001; Gambassi et al, 2006). In NLMS, postulated pathophysiologic mechanisms include central dopamine receptor dysregulation, autonomic dysfunction and skeletal muscle hypermetabolism (Bonnuccelli et al, 1991; Douglas \& Morris, 2006). In both cases, specific treatment remain controversial, but mostly relies on supportive treatments (e.g. antipyretics, intravenous fluids) and dopaminergic agonists, with variable results (Bonnuccelli et al, 1991; Colosimo et al, 1994; Wang \& Hsieh, 2001; Ikebe et al, 2003; Gambassi et al, 2006). Apomorphine, with its SC administration, rapid absorption into the brain and pleiotropic pharmacological profile, appears to be a good candidate for both NMS and NLMS (Colosimo et al, 1994; Wang \& Hsieh, 2001). A few successfully treated cases of NMS (Wang \& Hsieh, 2001; Lattanzi et al, 2006) and NLMS (Bonnuccelli et al, 1991; Cunningham et al, 1991; Douglas \& Morris, 2006), summarized in Table 4, support these assumptions. Briefly, in NMS, the initiation of apomorphine monotherapy (2mg every 3 to $4 \mathrm{~h})$ was rapidly followed $(<48 \mathrm{~h})$ by clinical improvement, with a decrease in muscle tone, fever and frequency of contractions (Wang \& Hsieh, 2001; Lattanzi et al, 2006; Gambassi et al, 2006). In two cases, apomorphine monotherapy successfully resolved the NMS within 4 days (Wang \& Hsieh, 2001; Lattanzi et al, 2006). In another case, the patient died despite partial remission of extrapyramidal signs (Gambassi et al, 2006). The delayed diagnosis might have prevented a favorable outcome in an already weakened patient (Gambassi et al, 2006), as prompt treatment is mandatory (Oruch et al, 2017). To be noted, the total daily dose of apomorphine was also lower (12 vs 16mg /day) in the latter case. The few reported cases of NMLS in PD $(\mathrm{N}=4)$ show that apomorphine, associated with L-dopa or other dopaminergic agonists, led to a quick resolution of the various symptoms (Bonnuccelli et al, 1991; Cunningham et al, 1991; Douglas \& Morris, 2006). Though not supported yet by major evidence (Oruch et al, 2017), SC apomorphine deserves to be considered as a good and practical alternative for NMS and NMLS, particularly when oral route is hindered (Wang \& Hsieh, 2001; Lattanzi et al, 2006; Douglas \& Morris, 2006). 


\section{ACCEPTED MANUSCRIPT}

Table 4: Summary of the case reports of NMS and NLMS treated with apomorphine. APO:

apomorphine; ATB: antibiotics: IV: intravenous; NLMS: neuroleptic-like malignant syndrome; NMS:

NLMS: neuroleptic malignant syndrome; PD : Parkinson's disease ; SC : subcutaneous; TID: three times a day

\begin{tabular}{|c|c|c|c|c|}
\hline Reference & $\begin{array}{l}\text { Patients' } \\
\text { characteristics } \\
\text { Drugs } \\
\text { incriminated }\end{array}$ & $\begin{array}{l}\text { Apomorphine } \\
\text { treatment }\end{array}$ & $\begin{array}{l}\text { Concomitant } \\
\text { treatment }\end{array}$ & Outcome \\
\hline $\begin{array}{l}\text { Wang \& } \\
\text { Hsieh, } 2001\end{array}$ & $\begin{array}{l}\text { - } 20 \text {-year old } \\
\text { female psychiatric } \\
\text { patient } \\
\text { - Haloperidol } \\
\text { (NMS) }\end{array}$ & $\begin{array}{l}\text { - SC monotherapy: } \\
2 \mathrm{mg} \text { every } 3 \mathrm{~h} \text { for } 3 \\
\text { days ( } 16 \mathrm{mg} / \text { day) } \\
\text { - Domperidone } 20 \\
\text { mg TID }\end{array}$ & None & $\begin{array}{l}\text { Rapid clinical improvement } \\
(<48 \mathrm{~h}) \\
\text { Reduction in muscle tone, } \\
\text { frequency of contractions \& } \\
\text { fever from the second day of } \\
\text { APO, reduction of creatinine } \\
\text { phosphokinase levels from the } \\
\text { third day. } \\
\text { Discharged } 10 \text { days later. }\end{array}$ \\
\hline $\begin{array}{l}\text { Lattanzi et } \\
\text { al, } 2001\end{array}$ & $\begin{array}{l}\text { - } 50 \text {-year old } \\
\text { female psychiatric } \\
\text { patient with bipolar } \\
\text { I disorder } \\
\text { - Chlorpromazine } \\
\text { \& amisulpride } \\
\text { (NMS) }\end{array}$ & $\begin{array}{l}\text { - SC monotherapy : } \\
2 \mathrm{mg} \text { every } 3 \mathrm{~h} \text { for } 3 \\
\text { days ( } 16 \mathrm{mg} / \text { day) } \\
\text { followed by } 2 \mathrm{mg} \\
\text { every } \\
6 \mathrm{~h} \text { for } 2 \text { additional } \\
\text { days ( } 8 \mathrm{mg} / \text { day) } \\
\text { - Domperidone } 20 \\
\mathrm{mg} \text { TID for } 2 \text { days }\end{array}$ & $\begin{array}{l}\text { IV } \\
\text { hydratation }\end{array}$ & $\begin{array}{l}\text { Improvement of all symptoms } \\
\text { within } 2 \text { days. } \\
\text { Complete disappearance after } 4 \\
\text { more days. }\end{array}$ \\
\hline $\begin{array}{l}\text { Gambassi et } \\
\text { al, } 2006\end{array}$ & $\begin{array}{l}\text { - 77-year old } \\
\text { diabetic man, with } \\
\text { mild depression, }\end{array}$ & $\begin{array}{l}\text { - SC monotherapy: } \\
2 \mathrm{mg} \text { every } 4 \mathrm{~h}(12 \\
\mathrm{mg} / \text { day })\end{array}$ & $\begin{array}{l}\text { - IV fluids, } \\
\text { - Insulin } \\
\text { - ATB }\end{array}$ & $\begin{array}{l}\text { Rapid initial improvement: } \\
\text { reduction in muscle tone, } \\
\text { frequency of contractions \& }\end{array}$ \\
\hline
\end{tabular}




\begin{tabular}{|c|c|c|c|c|}
\hline & & CCEP글 $M A$ & VUSCRIP' & \\
\hline & memory impairment & - Domperidone 10 & & fever from the second day of \\
\hline & and progressive & mg TID & & APO \\
\hline & cognitive & & & Severe respiratory and renal \\
\hline & deterioration & & & failure on the $3^{\text {rd }}$ day post-APO, \\
\hline & - Paroxetine \& & & & followed by death from cardio- \\
\hline & clozapine (NMS) & & & respiratory arrest 5 days later \\
\hline & & & & (aspiration pneumonia and \\
\hline & & & & disseminated intravascular \\
\hline & & & & coagulation) \\
\hline Douglas \& & - 76-year old & - SC (no dose & - L-dopa & Recovered within $48 \mathrm{~h}$ \\
\hline Morris, & woman with & indicated) for the & therapy & \\
\hline 2006 & idiopathic PD and & first $24 \mathrm{~h}$, followed & (nasogastric) & \\
\hline & aspiration & by & - Aggressive & 8 \\
\hline & pneumonia on & - nasogastric L- & cooling & \\
\hline & admission & Dopa & - IV & \\
\hline & - L-dopa reduction & & hydratation & \\
\hline & in a context of heat & & - ATB & \\
\hline & (summer) (NLMS) & & & \\
\hline Cunningham & - 41-year old & - CSAI, $1 \mathrm{mg} / \mathrm{h}$ over & - IV ATB & Improvement within $24 \mathrm{~h}$ after \\
\hline et al, 1991 & handicapped man & $10 \mathrm{~h}(10 \mathrm{mg})$ & - Addition of & addition of bromocriptine \\
\hline & with severe PD & - Domperidone & bromocriptine & \\
\hline & - Substitution of a & 20mg, 6-hourly & \& Modopar & \\
\hline & controlled-release & (nasogastric tube) & 125 & \\
\hline & formulation of L- & & - SC heparin, & \\
\hline & dopa (NLMS) & & IV fluids, & \\
\hline & & & pressure care, & \\
\hline & & & cooling, & \\
\hline & & & rectal & \\
\hline & & & paracetamol & \\
\hline
\end{tabular}




\section{ACCEPTED MANUSCRIPT}

\section{Apomorphine and cancer}

Several preclinical studies have demonstrated that apomorphine is a potential anticancer agent, with a wide spectrum of activity (see Table 1). As dopaminergic agonists are known to produce an antiproliferative effect on different cell lines (Schrell et al, 1990; Drewett et al, 1993; Chiarenza et al, 2003), and dopamine to play a role in several types of cancer (Jung \& Lee, 2017), the endocrine response to apomorphine (0.01 $\mathrm{mg} / \mathrm{kg} / \mathrm{body}$ weight) was assessed in cancer patients (Lissoni et al, 2003). Compared to the control group (6 males), GH and cortisol mean levels were significantly higher after apomorphine in the metastatic cancer patients (metastatic solid neoplasms, 10 males), suggesting an association between cancer progression and an altered dopaminergic sensitivity (Lissoni et al, 2003). In vitro experiments have shown that R-(-) and S-(+)apomorphine have a potent antiproliferative effect on various animal and human cancer cell lines (Table 1), and are able to suppress metastatic progression (Kondo et al, 1990; Seko et al, 1997; Scarselli et al, 1999; Maggio et al, 2000; Chiarenza et al, 2001; Pardini et al, 2003; Meredith et al, 2006; Jung \& Lee, 2017). Antiproliferative mechanisms involve oxidative stress (catechol moiety, Pardini et al, 2003), apoptotic cell death (Pardini et al, 2003; Meredith et al, 2006), mitochondrial regulation (Lee et al, 2016), as well as inhibition of several signaling pathways (glutaminase enzyme Thomas et al, 2013; ERK Jung \& Lee, 2017; interleukin IL-2 Kondo et al, 1990, protein kinase PKC/PKA Wang et al, 1997; Maggio et al, 1999; MDM2-p53 interaction Ishiba et al, 2017). These preliminary data are very encouraging, but whether they can be reproduced in vivo and harnessed to formulate a deliverable therapeutic remains uncertain (Meredith et al, 2006). However, a very recent in vivo study has shown that treatment with apomorphine $(5 \mathrm{mg} / \mathrm{kg}, 3$ times weekly for 1 month, a treatment protocol derived from previous AD model), prevented (human lung-derived) brain metastases formation in a NOD-SCID mice brain metastasis initiating cell model (Singh et al, 2018). Apomorphine induced an inhibition of micrometastatic growth as well as subsequent macrometastases, possibly through a targeting of premetastasisassociated genes (KIF16B, SEPW1, and TESK2) ; these results support further use of apomorphine in cancer therapy, particularly as a way to prevent metastases initiation (Singh et al, 2018). Studies exploring the possible anti-invasive effects of apomorphine on different types of cancer are currently underway (Jung \& Lee, 2017). Further work is needed to assert which types and forms of cancer are more likely to be targeted by apomorphine (potential candidates: glioma, glioblastoma, melanoma, meningioma, Lee et al, 2016; Singh et al, 2018), and precisely determine the mechanism(s) involved (regulatory effects on tumor progression and/or metastasis). 


\section{ACCEPTED MANUSCRIPT}

\section{Conclusion \& perspectives}

Fewer risks, lower costs and shorter timelines (Breckenridge \& Jacob, 2018) have prompted a renewed interest for repurposing old drugs. Apomorphine, a 150-year old pluripotent agent, seems to be an ideal candidate for repurposing. Historically, its use has certainly not been limited to PD, and even if some of these former indications have been consigned to history books, new prospects are emerging. This review fostered several repurposing opportunities for apomorphine. However, data are still scarce, and the fact that apomorphine may bring significant benefit in comparison with existing therapies in the previously mentioned indications has yet to be confirmed with larger, prospective randomized and placebo controlled studies. In addition, several pitfalls have to be overcome (Breckenridge \& Jacob, 2018) before a generalization of apomorphine use: legal, regulatory (phase II and III studies) and economic barriers (apomorphine being a mature drug), selecting the appropriate dose for each indication and patient, as well as offering new ways of administration and delivery systems. Another approach would be to synthetize apomorphine derivatives to overcome its inherent instability and short half-life, or to enhance targeting, with lipid-drug conjugates (Irby et al, 2017) or nanostructured lipid carriers (Hsu et al, 2010). Despite these limitations, there is now sufficient experimental evidence to support a rapid and efficient repurposing of apomorphine.

Financial disclosure:

- Dr Manon Auffret: none

- Dr Sophie Drapier served on scientific advisory boards for Orkyn and Aguettant, received speech honorarium from Orkyn, Aguettant, Medtronic, Teva and received PHRC grants from the French Ministry of Health.

- Pr Marc Vérin served on scientific advisory boards for Orkyn and Aguettant and received speech honorarium from Orkyn, Aguettant, Medtronic and Teva.

Funding source \& Conflict of interest: This research did not receive any specific grant from funding agencies in the public, commercial, or not-for-profit sectors. The authors declare that there are no conflicts of interest relevant to this work.

Conflicts of interest: No targeted funding reported. 


\section{References}

Afif-Abdo J, Teloken C, Damião R, Koff W, Wroclawski E, Yamasaki R, Torres LO, Sabaneeff J, Faria G, Pompeo AC, Cortado P, Glina S. Comparative cross-over study of sildenafil and apomorphine for treating erectile dysfunction. BJU Int. 2008 Sep;102(7):829-34. doi: 10.1111/j.1464410X.2008.07767.x. Epub 2008 Jun 4.

Albanese A, Cassetta E, Carretta D, Bentivoglio AR, Tonali P. Acute challenge with apomorphine in Huntington's disease: a double-blind study. Clin Neuropharmacol. 1995 Oct;18(5):427-34.

Albersen M, Shindel AW, Mwamukonda KB, Lue TF. The future is today: emerging drugs for the treatment of erectile dysfunction. Expert Opin Emerg Drugs. 2010 Sep;15(3):467-80. doi: 10.1517/14728214.2010.480973.

Altwein JE, Keuler FU. Oral treatment of erectile dysfunction with apomorphine SL. Urol Int. 2001;67(4):25763.

Auffret M, Drapier S, Vérin M. The Many Faces of Apomorphine: Lessons from the Past and Challenges for the Future. Drugs R D. 2018 Jun;18(2):91-107. doi: 10.1007/s40268-018-0230-3. $\rightarrow$ Auffret et al, 2018a

Auffret M, Drapier S, Vérin M. Pharmacological Insights into the Use of Apomorphine in Parkinson's Disease: Clinical Relevance. Clin Drug Investig. 2018 Apr;38(4):287-312. doi: 10.1007/s40261-018-0619-3. $\rightarrow$ Auffret et al, 2018b

Battaglia G, Busceti CL, Cuomo L, Giorgi FS, Orzi F, De Blasi A, Nicoletti F, Ruggieri S, Fornai F. Continuous subcutaneous infusion of apomorphine rescues nigro-striatal dopaminergic terminals following MPTP injection in mice. Neuropharmacology. 2002 Mar;42(3):367-73.

Bechara A, Bertolino MV, Casabe' A, Fredotovich N. A double blind randomized placebo control study comparing the objective and subjective changes in female sexual response using sublingual apomorphine. J Sex Med. 2004;1(2):209-14.

Beharry RK, Hale TM, Wilson EA, Heaton JP, Adams MA. Evidence for centrally initiated genital vasocongestive engorgement in the female rat: findings from a new model of female sexual arousal response. Int J Impot Res. 2003 Apr;15(2):122-8. 


\section{ACCEPTED MANUSCRIPT}

Bentivoglio AR, Albanese A, Granata R, Colosimo C, Tonali P. Apomorphine injections acutely improve chorea in patients with Huntington's disease. Mov Disord 1992;7 (Suppl):180.

Bonuccelli U, Piccini P, Corsini GU, Muratorio A. Apomorphine in malignant syndrome due to levodopa withdrawal. Ital J Neurol Sci. 1992 Mar;13(2):169-70.

Breckenridge A, Jacob R. Overcoming the legal and regulatory barriers to drug repurposing. Nat Rev Drug Discov. 2018 Jun 8. doi: 10.1038/nrd.2018.92. [Epub ahead of print]

Bronner G, Vodušek DB. Management of sexual dysfunction in Parkinson's disease. Ther Adv Neurol Disord. 2011 Nov;4(6):375-83. doi: 10.1177/1756285611411504.

Brunerova L, Potockova J, Horacek J, Koprivova H, Rehula M, Andel M. Sublingual apomorphine as a neuroendocrine probe. Psychiatry Res. 2012 Jul 30;198(2):297-9. doi: 10.1016/j.psychres.2011.09.022. Epub 2012 Mar 5.

Buster JE. Managing female sexual dysfunction. Fertil Steril. 2013 Oct;100(4):905-15. doi: 10.1016/j.fertnstert.2013.08.026.

Butcher LL, Butcher SG, Larsson K. Effects of apomorphine, (+)-amphetamine, and nialamide on tetrabenazineinduced suppression of sexual behavior in the male rat. Eur J Pharmacol. 1969 Sep;7(3):283-8.

Caraceni TA, Girotti F, Giovannini P, Pederzoli M, Parati EA. Effects of DA agonist in Huntington disease hyperkinesia. Ital J Neurol Sci. 1980 Jun;1(3):155-61.

Caruso S, Intelisano G, Farina M, DiMari L, Agnello C, Giammusso B. Efficacy and safety of daily intake of apomorphine SL in men affected by erectile dysfunction and mild hyperprolactinemia: a prospective, open-label, pilot study. Urology. 2003 Nov;62(5):922-7.

Caruso S, Agnello C, Intelisano G, Farina M, Di Mari L, Cianci A. Placebo-controlled study on efficacy and safety of daily apomorphine SL intake in premenopausal women affected by hypoactive sexual desire disorder and sexual arousal disorder. Urology. 2004;63(5):955-9.

Castri P, Busceti C, Battaglia G, et al. Protection by apomorphine in two independent models of acute inhibition of oxidative metabolism in rodents. Clin Exp Hypertens 2006;28:387-394.

Cepeda C, Murphy KP, Parent M, Levine MS. The role of dopamine in Huntington's disease. Prog Brain Res. 2014;211:235-54. doi: 10.1016/B978-0-444-63425-2.00010-6. 


\section{ACCEPTED MANUSCRIPT}

Chen YH, Huang EY, Kuo TT, Miller J, Chiang YH, Hoffer BJ. Impact of Traumatic Brain Injury on

Dopaminergic Transmission. Cell Transplant. 2017 Jul;26(7):1156-1168. doi:

10.1177/0963689717714105.

Chiarenza A, Scarselli M, Novi F, Lempereur L, Bernardini R, Corsini GU, Maggio R. Apomorphine, dopamine and phenylethylamine reduce the proportion of phosphorylated insulin receptor substrate 1 . Eur J Pharmacol. 2001 Dec 14;433(1):47-54.

Colosimo C, Merello M, Albanese A. Clinical usefulness of apomorphine in movement disorders. Clin Neuropharmacol. 1994 Jun;17(3):243-59.

Corsello SM, Bittker JA, Liu Z, Gould J, McCarren P, Hirschman JE, Johnston SE, Vrcic A, Wong B, Khan M, Asiedu J, Narayan R, Mader CC, Subramanian A, Golub TR. The Drug Repurposing Hub: a nextgeneration drug library and information resource. Nature Medicine (2017) 23, 405-408

Corsini GU, Onali P, Masala C, Cianchetti C, Mangoni A, Gessa G. Apomorphine hydrochloride-induced improvement in Huntington's chorea: stimulation of dopamine receptor. Arch Neurol. 1978 $\operatorname{Jan} ; 35(1): 27-30$.

Costa P. Multidimensional nature of apomorphine SL (Ixense) therapy. Int J Impot Res. 2003 Apr;15 Suppl 2:S13-5

Cunningham MA, Darby DG, Donnan GA. Controlled-release delivery of L-dopa associated with nonfatal hyperthermia, rigidity, and autonomic dysfunction. Neurology. 1991 Jun;41(6):942-3.

d'Emmanuele di Villa Bianca R1, Sorrentino R, Roviezzo F, Imbimbo C, Palmieri A, De Dominicis G, Montorsi F, Cirino G, Mirone V. Peripheral relaxant activity of apomorphine and of a D1 selective receptor agonist on human corpus cavernosum strips. Int J Impot Res. 2005 Mar-Apr;17(2):127-33.

Da Costa MM, Allen CE, Higginbottom A, Ramesh T, Shaw PJ, McDermott CJ. A new zebrafish model produced by TILLING of SOD1-related amyotrophic lateral sclerosis replicates key features of the disease and represents a tool for in vivo therapeutic screening. Dis Model Mech. 2014 Jan;7(1):73-81. doi: 10.1242/dmm.012013. Epub 2013 Oct 2.

DasGupta R, Fowler CJ. Bladder, bowel and sexual dysfunction in multiple sclerosis: management strategies. Drugs. 2003;63(2):153-66. 


\section{ACCEPTED MANUSCRIPT}

dos Santos El-Bachá R, Daval J, Koziel V, Netter P, Minn A. Toxic effects of apomorphine on rat cultured neurons and glial C6 cells, and protection with antioxidants. Biochem Pharmacol. 2001 Jan 1;61(1):7385.

Douglas A, Morris J. It was not just a heatwave! Neuroleptic malignant-like syndrome in a patient with Parkinson's disease. Age Ageing. 2006 Nov;35(6):640-1. Epub 2006 Aug 30.

Drewett N, Jacobi JM, Willgoss DA, Lloyd HM. Apoptosis in the anterior pituitary gland of the rat: studies with estrogen and bromocriptine. Neuroendocrinology. 1993 Jan;57(1):89-95.

European Medicine Agency (EMA). EU/3/12/954. Public summary of opinion on orphan designation: S[+] apomorphine for the treatment of amyotrophic lateral sclerosis. http://www.ema.europa.eu/ema/index.jsp?curl=pages/medicines/human/orphans/2012/03/human_orpha n_001028.jsp\&mid=WC0b01ac058001d12b

Flabeau O, Meissner WG, Tison F. Multiple system atrophy: current and future approaches to management. Ther Adv Neurol Disord. 2010 Jul;3(4):249-63. doi: 10.1177/1756285610375328.

Foreman MM, Moss RL. Role of hypothalamic dopaminergic receptors in the control of lordosis behavior in the female rat. Physiol Behav. 1979 Feb;22(2):283-9.

Fridman EA, Calvar J, Bonetto M, Gamzu E, Krimchansky BZ, Meli F, Leiguarda RC, Zafonte R. Fast awakening from minimally conscious state with apomorphine. Brain Inj. 2009 Feb;23(2):172-7. doi: $10.1080 / 02699050802649662$.

Fridman EA, Krimchansky BZ, Bonetto M, Galperin T, Gamzu ER, Leiguarda RC, Zafonte R. Continuous subcutaneous apomorphine for severe disorders of consciousness after traumatic brain injury. Brain Inj. 2010;24(4):636-41. doi: 10.3109/02699051003610433.

Friess E, Kuempfel T, Winkelmann J, Schmid D, Uhr M, Rupprecht R, Holsboer F, Trenkwalder C. Increased growth hormone response to apomorphine in Parkinson disease compared with multiple system atrophy. Arch Neurol. 2001 Feb;58(2):241-6.

Gambassi G, Capurso S, Tarsitani P, Liperoti R, Bernabei R. Fatal neuroleptic malignant syndrome in a previously long-term user of clozapine following its reintroduction in combination with paroxetine. Aging Clin Exp Res. 2006 Jun;18(3):266-70. 


\section{ACCEPTED MANUSCRIPT}

Gassen M, Glinka Y, Pinchasi B, Youdim MB. Apomorphine is a highly potent free radical scavenger in rat brain mitochondrial fraction. Eur J Pharmacol. 1996 Jul 18;308(2):219-25.

Gassen M, Gross A, Youdim MB. Apomorphine enantiomers protect cultured pheochromocytoma (PC12) cells from oxidative stress induced by H2O2 and 6-hydroxydopamine. Mov Disord. 1998 Jul;13(4):661-7.

Ghorayeb I, Dupouy S, Tison F, Meissner WG. Restless legs syndrome in multiple system atrophy. J Neural Transm (Vienna). 2014 Dec;121(12):1523-7. doi: 10.1007/s00702-014-1232-0. Epub 2014 May 13.

Giuliano F, Allard J. Apomorphine SL (Uprima): preclinical and clinical experiences learned from the first central nervous system-acting ED drug. Int J Impot Res. 2002 Feb;14 Suppl 1:S53-6.

Goldman ME, Kebabian JW. Aporphine enantiomers. Interactions with D-1 and D-2 dopamine receptors. Mol Pharmacol. 1984 Jan;25(1):18-23.

Graham MD, Pfaus J. Infusion of the dopamine agonist apomorphine to the medial preoptic are facilitates appetitive sexual behaviours of female rats. Abstract B-E2160, 2nd Annual Canadian Neuroscience Meeting (Canadian Association for Neuroscience), May 25-28, 2008, Montreal, Canada. https://www.can-acn.org/meeting2008/abstracts/416.htm

Grünblatt E, Mandel S, Berkuzki T, Youdim MB. Apomorphine protects against MPTP-induced neurotoxicity in mice. Mov Disord 1999;14:612-618. $\rightarrow$ Grünblatt et al, 1999a

Grünblatt E, Mandel S, Gassen M, Youdim MB. Potent neuroprotective and antioxidant activity of apomorphine in MPTP and 6-hydroxydopamine induced neurotoxicity. J Neural Transm Suppl 1999;55:57-70. $\rightarrow$ Grünblatt et al, 1999b

Grünblatt E, Mandel S, Maor G, Youdim MB. Effects of R- and S-apomorphine on MPTP-induced nigro-striatal dopamine neuronal loss. J Neurochem 2001;77:146-156.

Guardia J, Casas M, Prat G, Trujols J, Segura L, Sánchez-Turet M. The apomorphine test: a biological marker for heroin dependence disorder? Addict Biol. 2002 Oct;7(4):421-6.

Guo H, Tang Z, Yu Y, Xu L, Jin G, Zhou J. Apomorphine induces trophic factors that support fetal rat mesencephalic dopaminergic neurons in cultures. Eur J Neurosci. 2002 Nov;16(10):1861-70.

Gurkalo VK, Zabezhinskiı̌ MA. [Effects of apomorphine and haloperidol on experimental hepatocarcinogenesis]. Vopr Onkol. 1983;29(8):37-40. [Article in Russian] 


\section{ACCEPTED MANUSCRIPT}

Haba-Rubio J, Staner L, Cornette F, Lainey E, Luthringer R, Krieger J, Macher JP. Acute low single dose of apomorphine reduces periodic limb movements but has no significant effect on sleep arousals: a preliminary report. Neurophysiol Clin. 2003 Sep;33(4):180-4.

Hamburger-Bar R, Rigter H. Apomorphine: facilitation of sexual behaviour in female rats. Eur J Pharmacol. 1975;32(02):357-60.

Hanaki M, Murakami K, Katayama S, Akagi KI, Irie K. Mechanistic analyses of the suppression of amyloid $\beta 42$ aggregation by apomorphine. Bioorg Med Chem. 2018 May 1;26(8):1538-1546. doi: 10.1016/j.bmc.2018.01.028. Epub 2018 Feb 2.

Happe S, Bachmann CG, Helmschmied K, Neubert K, Wuttke W, Paulus W, Trenkwalder C. Growth hormone response to low-dose apomorphine in restless legs syndrome. Growth Horm IGF Res. 2007 Aug;17(4):323-7. Epub 2007 May 18.

Hara H, Ohta M, Adachi T. Apomorphine protects against 6-hydroxydopamine-induced neuronal cell death through activation of the Nrf2-ARE pathway. Journal of Neuroscience Research. 2006;84(4):860-866

Hardiman O, Al-Chalabi A, Chio A, Corr EM, Logroscino G, Robberecht W, Shaw PJ, Simmons Z, van den Berg LH. Amyotrophic lateral sclerosis. Nat Rev Dis Primers. 2017 Oct 5;3:17071. doi: 10.1038/nrdp.2017.71.

Hassan M, Dufor O, Merlet I, Berrou C, Wendling F. EEG source connectivity analysis: from dense array recordings to brain networks. PLoS One. 2014 Aug 12;9(8):e105041.

Heaton JP, Varrin SJ, Morales A. The characterization of a bio-assay of erectile function in a rat model. J Urol. 1991 May;145(5):1099-102.

Heaton JP, Varrin SJ. Effects of castration and exogenous testosterone supplementation in an animal model of penile erection. J Urol. 1994 Mar;151(3):797-800.

Heaton JP, Morales A, Adams MA, Johnston B, el-Rashidy R. Recovery of erectile function by the oral administration of apomorphine. Urology. 1995 Feb;45(2):200-6

Heaton JP. Characterising the benefit of apomorphine SL (Uprima) as an optimised treatment for representative populations with erectile dysfunction. Int J Impot Res. 2001 Aug;13 Suppl 3:S35-9. 


\section{ACCEPTED MANUSCRIPT}

Heaton JP, Dean J, Sleep DJ. Sequential administration enhances the effect of apomorphine SL in men with erectile dysfunction. Int J Impot Res. 2002 Feb;14(1):61-4.

Himeno E, Ohyagi Y, Ma L, Nakamura N, Miyoshi K, Sakae N, Motomura K, Soejima N, Yamasaki R, Hashimoto T, Tabira T, LaFerla FM, Kira J. Apomorphine treatment in Alzheimer mice promoting amyloid- $\beta$ degradation. Ann Neurol. 2011 Feb;69(2):248-56. doi: 10.1002/ana.22319.

Hsu SH, Wen CJ, Al-Suwayeh SA, Chang HW, Yen TC, Fang JY. Physicochemical characterization and in vivo bioluminescence imaging of nanostructured lipid carriers for targeting the brain: apomorphine as a model drug. Nanotechnology. 2010 Oct 8;21(40):405101. doi: 10.1088/0957-4484/21/40/405101. Epub 2010 Sep 8.

Huang X, Xiong C, Zhou J, Shen J. Effect of sublingual medication of sildenafil citrate/ apomorphine on sexual behaviour of male rats. Andrologia. 2009 Apr;41(2):71-5. doi: 10.1111/j.1439-0272.2008.00860.x.

Ikebe S, Harada T, Hashimoto T, Kanazawa I, Kuno S, Mizuno Y, Mizuta E, Murata M, Nagatsu T, Nakamura S, Takubo H, Yanagisawa N, Narabayashi H. Prevention and treatment of malignant syndrome in Parkinson's disease: a consensus statement of the malignant syndrome research group. Parkinsonism Relat Disord. 2003 Apr;9 Suppl 1:S47-9.

Irby D, Du C, Li F. Lipid-Drug Conjugate for Enhancing Drug Delivery. Mol Pharm. 2017 May 1;14(5):13251338. doi: 10.1021/acs.molpharmaceut.6b01027. Epub 2017 Jan 24. Review.

Ishiba H, Noguchi T, Shu K, Ohno H, Honda K, Kondoh Y, Osada H, Fujii N, Oishi S. Investigation of the inhibitory mechanism of apomorphine against MDM2-p53 interaction. Bioorg Med Chem Lett. 2017 Jun 1;27(11):2571-2574. doi: 10.1016/j.bmcl.2017.03.082. Epub 2017 Mar 29.

Ishizuka O, Gu BJ, Nishizawa O, Mizusawa H, Andersson KE. Effect of apomorphine on intracavernous pressure and blood pressure in conscious, spinalized rats. Int J Impot Res. 2002 Apr;14(2):128-32.

Jung YS, Lee SO. Apomorphine suppresses TNF- $\alpha$-induced MMP-9 expression and cell invasion through inhibition of ERK/AP-1 signaling pathway in MCF-7 cells. Biochem Biophys Res Commun. 2017 Jun 10;487(4):903-909. doi: 10.1016/j.bbrc.2017.04.151. Epub 2017 May 2.

Kieburtz K, Reilmann R, Olanow CW. Huntington's disease: Current and future therapeutic prospects. Mov Disord. 2018 May 8. doi: 10.1002/mds.27363. 


\section{ACCEPTED MANUSCRIPT}

Kondo Y, Imai Y, Hojo H, Endo T, Nozoe S. Suppression of tumor cell growth and mitogen response by aporphine alkaloids, dicentrine, glaucine, corydine, and apomorphine. J Pharmacobiodyn. 1990 Jul;13(7):426-31.

Kyriazis M. Neuroprotective, anti-apoptotic effects of apomorphine. J Anti Aging Med. 2003 Spring;6(1):21-8.

Lammers PI, Rubio-Aurioles E, Castell R, Castaneda J, Ponce de Leon R, Hurley D, Lipezker M, Loehr LA, Lowrey F. Combination therapy for erectile dysfunction: a randomized, double blind, unblinded activecontrolled, cross-over study of the pharmacodynamics and safety of combined oral formulations of apomorphine hydrochloride, phentolamine mesylate and papaverine hydrochloride in men with moderate to severe erectile dysfunction. Int J Impot Res. 2002 Feb;14(1):54-9; discussion 60.

Lal S, De la Vega C, Garelis E, Sourkes TL. Apomorphine, pimozide, L-Dopa and the probenecid test in Huntington's chorea. Psychiatr Neurol Neurochir. 1973 Mar-Apr;76(2):113-7.

Lal S, De la Vega C. Apomorphine and psychopathology. JNNP 1975;38:722-726.

Lal S, Tesfaye Y, Thavundayil JX, Thompson TR, Kiely ME, Nair NP, Grassino A, Dubrovsky B. Apomorphine: clinical studies on erectile impotence and yawning. Prog Neuropsychopharmacol Biol Psychiatry. 1989;13(3-4):329-39.

Lashuel HA, Hartley DM, Balakhaneh D, Aggarwal A, Teichberg S, Callaway DJ. New class of inhibitors of amyloid-beta fibril formation. Implications for the mechanism of pathogenesis in Alzheimer's disease. $\mathrm{J}$ Biol Chem. 2002 Nov 8;277(45):42881-90. Epub 2002 Aug 6.

Lattanzi L, Mungai F, Romano A, Bonuccelli U, Cassano GB, Fagiolini A. Subcutaneous apomorphine for neuroleptic malignant syndrome. Am J Psychiatry. 2006 Aug;163(8):1450-1.

Lee H, Kang S, Kim W. Drug Repositioning for Cancer Therapy Based on Large-Scale Drug-Induced Transcriptional Signatures. PLoS One. 2016 Mar 8;11(3):e0150460. doi: 10.1371/journal.pone.0150460.

Li A, Guo H, Luo X, Sheng J, Yang S, Yin Y, Zhou J, Zhou J. Apomorphine-induced activation of dopamine receptors modulates FGF-2 expression in astrocytic cultures and promotes survival of dopaminergic neurons. FASEB J. 2006 Jun;20(8):1263-5. Epub 2006 Apr 24. 


\section{ACCEPTED MANUSCRIPT}

Lissoni P, Malugani F, Manganini V, Ardizzoia A, Gardani G, Bartolacelli E, Messina G, Tancini G.

Psychooncology and cancer progression-related alterations of pleasure-associated neurochemical system: Abnormal neuroendocrine response to apomorphine in advanced cancer patients. Neuro Endocrinol Lett. 2003 Feb-Apr;24(1-2):50-3.

Ma L, Ohyagi Y, Nakamura N, Iinuma KM, Miyoshi K, Himeno E, Soejima N, Yanagihara YT, Sakae N, Yamasaki R, Kira J. Activation of glutathione peroxidase and inhibition of p53-related apoptosis by apomorphine. J Alzheimers Dis. 2011;27(1):225-37. doi: 10.3233/JAD-2011-110140.

Maclennan KM, Boshier A, Wilton LV, Shakir SA. Examination of the safety and use of apomorphine prescribed in general practice in England as a treatment for erectile dysfunction. BJU Int. 2006 Jul;98(1):125-31.

Maggio R, Armogida M, Scarselli M, Salvadori F, Longoni B, Pardini C, Chiarenza A, Chiacchio S, Vaglini F, Bernardini R, Colzi A, Corsini GU. Dopamine agonists and analogues have an antiproliferative effect on CHO-K1 cells. Neurotox Res. 2000 Apr;1(4):285-97.

Malmnäs CO. Dopaminergic reversal of the decline after castration of rat copulatory behaviour. J Endocrinol. 1977 Apr;73(1):187-8.

Mandel S, Maor G, Youdim MB. Iron and a-synuclein in the substantia nigra of MPTP-treated mice: effect of neuroprotective drugs R-apomorphine and green tea polyphenol (-)-epigallocatechin- 3-gallate. J Mol Neurosci 2004;24:401-416.

Mano T, Thomas RJ. Anatomo-functional basis of restless legs syndrome. Neurology. 2018 May 22;90(21):945946. doi: 10.1212/WNL.0000000000005573.

Manson AJ, Hanagasi H, Turner K, Patsalos PN, Carey P, Ratnaraj N, Lees AJ. Intravenous apomorphine therapy in Parkinson's disease: clinical and pharmacokinetic observations. Brain. 2001 Feb;124(Pt 2):331-40.

Masters CL, Bateman R, Blennow K, Rowe CC, Sperling RA, Cummings JL. Alzheimer's disease. Nat Rev Dis Primers. 2015 Oct 15;1:15056. doi: 10.1038/nrdp.2015.56. Review.

Matsumoto K, Yoshida M, Andersson KE, Hedlund P. Effects in vitro and in vivo by apomorphine in the rat corpus cavernosum. Br J Pharmacol. 2005 Sep;146(2):259-67. 


\section{ACCEPTED MANUSCRIPT}

McColgan P, Tabrizi SJ. Huntington's disease: a clinical review. Eur J Neurol. 2018 Jan;25(1):24-34. doi: 10.1111/ene.13413. Epub 2017 Sep 22.

Mead RJ, Higginbottom A, Allen SP, Kirby J, Bennett E, Barber SC, Heath PR, Coluccia A, Patel N, Gardner I, Brancale A, Grierson AJ, Shaw PJ. S[+] Apomorphine is a CNS penetrating activator of the Nrf2-ARE pathway with activity in mouse and patient fibroblast models of amyotrophic lateral sclerosis Free Radic Biol Med. 2013 Aug; 61: 438-452. doi: 10.1016/j.freeradbiomed.2013.04.018

Mehndiratta MM, Wadhai SA, Tyagi BK, Gulati NS, Sinha M. Drug repositioning. International Journal of Epilepsy, Volume 3, Issue 2, 2016, Pages 91-94, ISSN 22136320,https://doi.org/10.1016/j.ijep.2016.09.002.

Melis MR, Argiolas A, Gessa GL. Apomorphine-induced penile erection and yawning: site of action in brain. Brain Res. 1987 Jul 7;415(1):98-104.

Melis MR, Mauri A, Argiolas A. Apomorphine-and oxytocin-induced penile erection and yawning in intact and castrated male rats: effect of sexual steroids. Neuroendocrinology. 1994 Apr;59(4):349-54.

Meredith EJ, Holder MJ, Rosén A, Lee AD, Dyer MJ, Barnes NM, Gordon J. Dopamine targets cycling B cells independent of receptors/transporter for oxidative attack: Implications for non-Hodgkin's lymphoma. Proc Natl Acad Sci U S A. 2006 Sep 5;103(36):13485-90.

Mohee A, Bretsztajn L, Eardley I. The evaluation of apomorphine for the treatment of erectile dysfunction. Expert Opin Drug Metab Toxicol. 2012 Nov;8(11):1447-53. doi: 10.1517/17425255.2012.727797. Epub 2012 Sep 24.

Montorsi F, Perani D, Anchisi D, Salonia A, Scifo P, Rigiroli P, Zanoni M, Heaton JP, Rigatti P, Fazio F. Apomorphine-induced brain modulation during sexual stimulation: a new look at central phenomena related to erectile dysfunction. Int J Impot Res. 2003 Jun;15(3):203-9. $\rightarrow$ Montorsi 2003a

Montorsi F. Tolerability and safety of apomorphine SL (Ixense (TM) ). Int J Impot Res. 2003 Apr;15 Suppl 2:S7-9. $\rightarrow$ Montorsi 2003b

Morales A. Apomorphine to Uprima: the development of a practical erectogenic drug: a personal perspective. Int J Impot Res. 2001 Aug;13 Suppl 3:S29-34. 


\section{ACCEPTED MANUSCRIPT}

Müller T, Marg M, Rothe H, Küchler M. Continuous Subcutaneous Apomorphine Infusion Improves Severe Restless Legs Syndrome. Mov Disord Clin Pract 2014, 1: 233-234. doi:10.1002/mdc3.12039

Nabavi SM, Uriarte E, Rastrelli L, Sobarzo-Sanchez E. Aporphines and Alzheimer's disease: Towards a Medical Approach Facing the Future. Curr Med Chem. 2018 May 13. doi: $10.2174 / 0929867325666180514102933$.

Nakamura N, Ohyagi Y, Imamura T, Yanagihara YT, Iinuma KM, Soejima N, Murai H, Yamasaki R, Kira JI. Apomorphine Therapy for Neuronal Insulin Resistance in a Mouse Model of Alzheimer's Disease. J Alzheimers Dis. 2017;58(4):1151-1161. doi: 10.3233/JAD-160344.

NIH Consensus Conference. Impotence. NIH Consensus Development Panel on Impotence. JAMA. 1993 Jul 7; 270(1):83-90

O'Sullivan JD1, Hughes AJ. Apomorphine-induced penile erections in Parkinson's disease. Mov Disord. 1998 May;13(3):536-9.

Ohta M, Mizuta I, Ohta K, Nishimura M, Mizuta E, Hayashi K, Kuno S. Apomorphine up-regulates NGF and GDNF synthesis in cultured mouse astrocytes. Biochem Biophys Res Commun. 2000 May $27 ; 272(1): 18-22$.

Ohyagi Y. Apomorphine: A Novel Efficacy for Alzheimer's Disease and Its Mechanisms. J Alzheimers Dis Parkinsonism 2012 2:e122. doi:10.4172/2161-0460.1000e122

Oruch R, Pryme IF, Engelsen BA, Lund A. Neuroleptic malignant syndrome: an easily overlooked neurologic emergency. Neuropsychiatr Dis Treat. 2017 Jan 16;13:161-175. doi: 10.2147/NDT.S118438.

Paradiso G, Khan F, Chen R. Effects of apomorphine on flexor reflex and periodic limb movement. Mov Disord. 2002 May;17(3):594-7.

Pardini C, Vaglini F, Galimberti S, Corsini GU. Dose-dependent induction of apoptosis by R-apomorphine in CHO-K1 cell line in culture. Neuropharmacology. 2003 Aug;45(2):182-9.

Park JY, Son H, Kim SW, Paick JS. Potentiation of apomorphine effect on sildenafil-induced penile erection in conscious rabbits. Asian J Androl. 2004 Sep;6(3):205-9. 


\section{ACCEPTED MANUSCRIPT}

Pehek EA, Thompson JT, Hull EM. The effects of intrathecal administration of the dopamine agonist apomorphine on penile reflexes and copulation in the male rat. Psychopharmacology (Berl). $1989 ; 99(3): 304-8$

Perez-Lloret S, Flabeau O, Fernagut P, Pavy-Le Traon A, Rey M V, Foubert-Samier A, Tison F, Rascol O, Meissner WG. Current Concepts in the Treatment of Multiple System Atrophy. Mov Disord Clin Pract 2015, 2: 6-16. doi:10.1002/mdc3.12145

Perimenis P, Markou S, Gyftopoulos K, Giannitsas K, Athanasopoulos A, Liatsikos E, Barbalias G. Efficacy of apomorphine and sildenafil in men with nonarteriogenic erectile dysfunction. A comparative crossover study. Andrologia. 2004 Jun;36(3):106-10.

Picada JN, Roesler R, Henriques JA. Genotoxic, neurotoxic and neuroprotective activities of apomorphine and its oxidized derivative 8-oxo-apomorphine. Braz J Med Biol Res. 2005 Apr;38(4):477-86. Epub 2005 Apr 13.

Pinheiro T, Otrocka M, Seashore-Ludlow B, Rraklli V, Holmberg J, Forsberg-Nilsson K, Simon A, Kirkham M. Reprint of: A chemical screen identifies trifluoperazine as an inhibitor of glioblastoma growth. Biochem Biophys Res Commun. 2018 May 5;499(2):136-142. doi: 10.1016/j.bbrc.2018.03.001. Epub 2018 Mar 23.

Pistoia F, Mura E, Govoni S, Fini M, Sarà M. Awakenings and awareness recovery in disorders of consciousness: is there a role for drugs? CNS Drugs. 2010 Aug;24(8):625-38. doi: 10.2165/11535940000000000-00000.

Porst H, Behre HM, Jungwirth A, Burkart M. Comparative trial of treatment satisfaction, efficacy and tolerability of sildenafil versus apomorphine in erectile dysfunction--an open, randomized cross-over study with flexible dosing. Eur J Med Res. 2007 Feb 26;12(2):61-7.

Raju TN. The Nobel chronicles. 1988: James Whyte Black, (b 1924), Gertrude Elion (1918-99), and George H Hitchings (1905-98). Lancet. 2000 Mar 18;355(9208):1022.

Reuter I, Ellis CM, Ray Chaudhuri K. Nocturnal subcutaneous apomorphine infusion in Parkinson's disease and restless legs syndrome. Acta Neurol Scand. 1999 Sep;100(3):163-7. 


\section{ACCEPTED MANUSCRIPT}

Ribarič S. The pharmacological properties and therapeutic use of apomorphine. Molecules. 2012 May

7;17(5):5289-309. doi: 10.3390/molecules 17055289.

Riley A, Main M, Morgan F. Inhalation device allows novel administration of apomorphine in men with erectile dysfunction-efficacy and safety findings. J Sex Med. 2010 Apr;7(4 Pt 1):1508-17. doi: 10.1111/j.17436109.2009.01540.x. Epub 2009 Oct 20.

Sam EE, Verbeke N. Free radical scavenging properties of apomorphine enantiomers and dopamine: possible implication in their mechanism of action in parkinsonism. J Neural Transm Park Dis Dement Sect. $1995 ; 10(2-3): 115-27$

Sanberg PR, Lehmann J, Fibiger HC. Sedative effects of apomorphine in an animal model of Huntington's disease. Arch Neurol. 1979 Jun;36(6):349-50.

Scaletta LL, Hull EM. Systemic or intracranial apomorphine increases copulation in long-term castrated male rats. Pharmacol Biochem Behav. 1990 Nov;37(3):471-5.

Scarselli M, Barbier P, Salvadori F, Armogida M, Collecchi P, Pardini C, Vaglini F, Maggio R, Corsini GU. Apomorphine has a potent antiproliferative effect on Chinese hamster ovary cells. J Neural Transm Suppl. 1999;55:47-55.

Schrell UM, Fahlbusch R, Adams EF, Nomikos P, Reif M. Growth of cultured human cerebral meningiomas is inhibited by dopaminergic agents. Presence of high affinity dopamine-D1 receptors. J Clin Endocrinol Metab. 1990 Dec;71(6):1669-71.

Schulze A, Oehler B, Urban N, Schaefer M, Hill K. Apomorphine is a bimodal modulator of TRPA1 channels. Mol Pharmacol. 2013 Feb;83(2):542-51. doi: 10.1124/mol.112.081976. Epub 2012 Dec 6.

Schwab LC, Garas SN, Drouin-Ouellet J, Mason SL, Stott SR, Barker RA. Dopamine and Huntington's disease. Expert Rev Neurother. 2015 Apr;15(4):445-58. doi: 10.1586/14737175.2015.1025383. Epub 2015 Mar 16.

Seko Y, Tanaka Y, Tokoro T. Apomorphine inhibits the growth-stimulating effect of retinal pigment epithelium on scleral cells in vitro. Cell Biochem Funct. 1997 Sep;15(3):191-6.

Singh M, Venugopal C, Tokar T, McFarlane N, Subapanditha MK, Qazi M, Bakhshinyan D, Vora P, Murty NK, Jurisica I, Singh SK. Therapeutic Targeting of the Premetastatic Stage in Human Lung-to-Brain 


\section{ACCEPTED MANUSCRIPT}

Metastasis. Cancer Res. 2018 Sep 1;78(17):5124-5134. doi: 10.1158/0008-5472.CAN-18-1022. Epub 2018 Jul 9.

Solayman MH, Badary OA, Salem KA, El-Hamamsy. PIH4 Is Sildenafil - Apomorphine Sublingual Combination Significantly More Effective than Sublingual Sildenafil in Treating Erectile Dysfunction? Value in Health, 2012 June ;15(4)A192

Steele JW, Gandy S. Apomorphine and Alzheimer A $\beta$ : roles for regulated $\alpha$ cleavage, autophagy, and antioxidation? Ann Neurol. 2011 Feb;69(2):221-5. doi: 10.1002/ana.22359.

Strebel RT, Reitz A, Tenti G, Curt A, Hauri D, Schurch B. Apomorphine sublingual as primary or secondary treatment for erectile dysfunction in patients with spinal cord injury. BJU Int. 2004 Jan;93(1):100-4.

Tagliamonte A, Fratta W, Gessa GL. Aphrodisiac effect of L-DOPA and apomorphine in male sexually sluggish rats. Experientia. 1974 Apr 15;30(4):381-2.

Tarcan T, Siroky MB, Park K, Goldstein I, Azadzoi KM. Systemic administration of apomorphine improves the hemodynamic mechanism of clitoral and vaginal engorgement in the rabbit. Int J Impot Res. $2000 ; 12(4): 235-40$.

Thomas AG, Rojas C, Tanega C, Shen M, Simeonov A, Boxer MB, Auld DS, Ferraris DV, Tsukamoto T, Slusher BS. Kinetic characterization of ebselen, chelerythrine and apomorphine as glutaminase inhibitors. Biochem Biophys Res Commun. 2013 Aug 23;438(2):243-8. doi: 10.1016/j.bbrc.2013.06.110.

Tolosa ES, Sparber SB. Apomorphine in Huntington's chorea: clinical observations and theoretical considerations. Life Sci. 1974 Oct 1;15(7):1371-80.

Tings T, Stiens G, Paulus W, Trenkwalder C, Happe S. Treatment of restless legs syndrome with subcutaneous apomorphine in a patient with short bowel syndrome. J Neurol. 2005 Mar;252(3):361-3. Epub 2005 Feb 23.

Tribl GG, Sycha T, Kotzailias N, Zeitlhofer J, Auff E. Apomorphine in idiopathic restless legs syndrome: an exploratory study. J Neurol Neurosurg Psychiatry. 2005 Feb;76(2):181-5. DOI: 10.1136/jnnp.2003.034843 


\section{ACCEPTED MANUSCRIPT}

Ubeda A, Montesinos C, Payá M, Alcaraz MJ. Iron-reducing and free-radical-scavenging properties of apomorphine and some related benzylisoquinolines. Free Radic Biol Med. 1993 Aug;15(2):159-67.

Varrin S, Heaton JP. Age-related changes in apomorphine-induced erections. Neurobiol Aging. 1992 JanFeb;13(1):175-7.

Vitale C, Marconi S, Di Maio L, De Michele G, Longo K, Bonavita V, Barone P. Short-term continuous infusion of apomorphine hydrochloride for treatment of Huntington's chorea: A double blind, randomized crossover trial. Mov Disord. 2007 Dec;22(16):2359-64.

Wang J, Gu BJ, Masters CL, Wang YJ. A systemic view of Alzheimer disease - insights from amyloid- $\beta$ metabolism beyond the brain. Nat Rev Neurol. 2017 Nov;13(11):703. doi: 10.1038/nrneurol.2017.147.

Wang HC, Hsieh Y. Treatment of neuroleptic malignant syndrome with subcutaneous apomorphine monotherapy. Mov Disord. 2001 Jul;16(4):765-7.

Winkelmann J, Allen RP, Högl B, Inoue Y, Oertel W, Salminen AV, Winkelman JW, Trenkwalder C, Sampaio C. Treatment of restless legs syndrome: Evidence-based review and implications for clinical practice (Revised 2017)§. Mov Disord. 2018 May 14. doi: 10.1002/mds.27260.

Yarnall AJ, Lashley T, Ling H, Lees AJ, Coleman SY, O'Sullivan SS, Compta Y, Revesz T, Burn DJ. Apomorphine: A potential modifier of amyloid deposition in Parkinson's disease? Mov Disord. 2016 May;31(5):668-75. doi: 10.1002/mds.26422. Epub 2015 Oct 13.

Youdim MB, Grünblatt E, Mandel S. The pivotal role of iron in NF-kappa B activation and nigrostriatal dopaminergic neurodegeneration. Prospects for neuroprotection in Parkinson's disease with iron chelators. Ann N Y Acad Sci. 1999;890:7-25.

Yuan H, Sarre S, Ebinger G, Michotte Y. Neuroprotective and neurotrophic effect of apomorphine in the striatal 6-OHDA-lesion rat model of Parkinson's disease. Brain Res. 2004 Nov 5;1026(1):95-107.

Yuan S, Zhang ZW, Li ZL. Cell Death-Autophagy Loop and Glutamate-Glutamine Cycle in Amyotrophic Lateral Sclerosis. Front Mol Neurosci. 2017; 10: 231. Published online 2017 Jul 21. doi: 10.3389/fnmol.2017.00231

Author Roles: 


\section{ACCEPTED MANUSCRIPT}

- Dr Manon Auffret: conception and design of the research, analysis and interpretation, drafting the article, final approval of the version to be submitted.

- Dr Sophie Drapier: revising the article critically for important intellectual content, final approval of the version to be submitted.

- Pr Marc Vérin: revising the article critically for important intellectual content, final approval of the version to be submitted. 